medRxiv preprint doi: https://doi.org/10.1101/2021.04.16.21251163; this version posted April 16, 2021. The copyright holder for this preprint

(which was not certified by peer review) is the author/funder, who has granted medRxiv a license to display the preprint in perpetuity.

It is made available under a CC-BY-NC-ND 4.0 International license .

2

3

4

5

6

7

8

9

10

11

12

13

14

15

16

17

18

19

20

21

22

23

24

25

26

27

28

29

30

31

32

33

34

35

36

37

38

39

40

41

42

43

44

45

46

47

48

49

\title{
Characterization of Age and Polarity at Onset in Bipolar Disorder
}

Janos L. Kalman ${ }^{1,2,3}, \mathrm{MD},{ }^{*}$ Loes M. Olde Loohuis ${ }^{4}, \mathrm{PhD},{ }^{*}$ Annabel Vreeker ${ }^{5}, \mathrm{PhD}$, ${ }^{*}$ Andrew McQuillin ${ }^{6}$, PhD, Eli A. Stahl ${ }^{7}, \mathrm{PhD}$, Douglas Ruderfer ${ }^{8,9,10}, \mathrm{PhD}$, Maria Grigoroiu-Serbanescu ${ }^{11}$, PhD, Georgia Panagiotaropoulou ${ }^{12}$, M.Sc., Stephan Ripke ${ }^{13,14}$, M.D., Ph.D., Tim B Bigdeli ${ }^{15,16}$, PhD, Frederike Stein ${ }^{17}$, M.A., Tina Meller $^{17,18}$, Dr. rer. nat., M.Sc., Susanne Meinert ${ }^{19}$, M.Sc., Helena Pelin ${ }^{3,20}$, M.Sc., Fabian Streit ${ }^{21}$, PhD, Sergi Papiol ${ }^{1,2,22}, \mathrm{PhD}$, Mark J Adams s3, PhD, Rolf Adolfsson ${ }^{24}$, $\mathrm{MD}$, PhD, Kristina Adorjan ${ }^{1,2}, \mathrm{MD}$, Ingrid Agartz ${ }^{25,26,27}, \mathrm{MD}$, PhD, Sofie R. Aminoff ${ }^{28,29}, \mathrm{PhD}$, Heike Anderson-Schmidt ${ }^{30}$, Dipl-Psych, Ole A. Andreassen ${ }^{29,31}$, MD, PhD, Raffaella Ardau ${ }^{32}$, Jean-Michel Aubry ${ }^{33,34}$, MD, Ceylan Balaban ${ }^{35}$, M.Sc., Nicholas Bass ${ }^{6}$, MRCPsych, Bernhard T Baune ${ }^{19}$, MD, PhD, Frank Bellivier ${ }^{36,37,38}$, $\mathrm{MD}, \mathrm{PhD}$, Antonio Benabarre ${ }^{39}, \mathrm{MD}, \mathrm{PhD}$, Susanne Bengesser ${ }^{40}, \mathrm{MD}, \mathrm{PhD}$, Wade $\mathrm{H}$ Berrettini $^{41}, \mathrm{MD}, \mathrm{PhD}$, Marco P. Boks ${ }^{42}, \mathrm{MD}, \mathrm{PhD}$, Evelyn J Bromet ${ }^{43}, \mathrm{PhD}$, Katharina Brosch ${ }^{17}$, M.Sc., Monika Budde ${ }^{1}$, Dipl-Psych, William Byerley ${ }^{44}$, MD, Pablo Cervantes $^{45}$, MD, Catina Chillotti ${ }^{32}$, Sven Cichon ${ }^{46,47,48,49}$, Prof. Dr. rer.nat., Scott $R$ Clark $^{50,51}, \mathrm{MD}$, PhD, Ashley L. Comes ${ }^{1,3}, \mathrm{PhD}$, Aiden Corvin ${ }^{52}, \mathrm{MD}, \mathrm{PhD}$, William Coryell ${ }^{53}, \mathrm{MD}$, Nick Craddock ${ }^{54}, \mathrm{MD}$, David W. Craig ${ }^{55}$, PhD, Paul E. Croarkin ${ }^{56}$, D.O., M.S., Cristiana Cruceanu ${ }^{3}$, PhD, Piotr M. Czerski ${ }^{57}, \mathrm{PhD}$, Nina Dalkner ${ }^{40}, \mathrm{PhD}$, Udo Dannlowski ${ }^{19}$, MD, PhD, Franziska Degenhardt47,58, MD, J. Raymond DePaulo ${ }^{59}, \mathrm{MD}$, Srdjan Djurovic ${ }^{60,61}, \mathrm{PhD}$, Howard J. Edenberg ${ }^{62}$, PhD, Mariam Al Eissa $^{6}, \mathrm{PhD}$, Torbjørn Elvsåshagen ${ }^{63}, \mathrm{MD}, \mathrm{PhD}$, Bruno Etain ${ }^{36,37,38}, \mathrm{MD}, \mathrm{PhD}$, Ayman H Fanous ${ }^{15,16}, \mathrm{MD}$, Frederike Fellendorf ${ }^{40}, \mathrm{MD}$, Alessia Fiorentino ${ }^{6}, \mathrm{PhD}$, Andreas J Forstner ${ }^{47,64}$, MD, Mark A. Frye ${ }^{56}, \mathrm{MD}$, Janice M. Fullerton ${ }^{65,66}, \mathrm{PhD}$, Katrin Gade ${ }^{67}, M D$, Julie Garnham ${ }^{68}$, BN RN, Kirov George ${ }^{54}, \mathrm{PhD}, \mathrm{MD}$, Elliot Gershon $^{69,70}$, MD, Michael Gill ${ }^{52}$, MD, Fernando S. Goes ${ }^{59}$, MD, Katherine GordonSmith $^{71}$, PhD, Paul Grof ${ }^{72,73}, \mathrm{MD}, \mathrm{PhD}$, Jose Guzman-Parra ${ }^{74}, \mathrm{PhD}$, Tim Hahn ${ }^{19}$, $\mathrm{PhD}$, Maria Hake ${ }^{1}$, Dipl.-Psych., Roland Hasler ${ }^{33,34}$, PhD, Urs Heilbronner ${ }^{1}, \mathrm{PhD}$, Stephane Jamain ${ }^{75,76}, \mathrm{PhD}$, Esther Jimenez ${ }^{39}, \mathrm{MSc}, \mathrm{PhD}$, lan Jones ${ }^{54}, \mathrm{PhD}, \mathrm{MD}$, Lisa Jones ${ }^{71}, \mathrm{MD}$, Lina Jonsson ${ }^{77}, \mathrm{MSc}$, Rene S Kahn ${ }^{78}, \mathrm{MD}, \mathrm{PhD}$, John R. Kelsoe $^{79}$, MD, James L. Kennedy ${ }^{73,80,81}$, MD, Tilo Kircher ${ }^{17}$, MD, Sarah KittelSchneider ${ }^{35,82}$, MD, Farah Klöhn-Saghatolislam ${ }^{1}$, MD, MBA, James A Knowles ${ }^{83,84}$, $\mathrm{MD}$, PhD, Thorsten Manfred Kranz ${ }^{35}, \mathrm{PhD}$, Trine Vik Lagerberg ${ }^{31,63}, \mathrm{PhD}$, Mikael Landen $^{77,85}, \mathrm{MD}$, PhD, William B Lawson ${ }^{86}$, MD, Marion Leboyer ${ }^{75,76}, \mathrm{MD}$, PhD, Qingqin S Li ${ }^{87}$, PhD, Mario Maj ${ }^{88}, \mathrm{MD}$, PhD, Dolores Malaspina ${ }^{78,89}, \mathrm{MD}, \mathrm{MS}, \mathrm{MSPH}$, Mirko Manchia ${ }^{90,91}, \mathrm{MD}, \mathrm{PhD}$, Fermin Mayoral ${ }^{74}, \mathrm{PhD}, \mathrm{MDF}$, Susan L McElroy ${ }^{92}, \mathrm{MD}$, Melvin G Mclnnis ${ }^{93}, \mathrm{MD}$, Andrew M Mclntosh ${ }^{23}$, MD, FRCPsych, Helena Medeiros ${ }^{84}$, MSW, LICSW, Ingrid Melle ${ }^{27,28}, \mathrm{MD}, \mathrm{PhD}$, Vihra Milanova ${ }^{94}, \mathrm{MD}, \mathrm{PhD}$, Philip B. Mitchell $^{95}, \mathrm{MD}$, Palmiero Monteleone ${ }^{96}, \mathrm{MD}$, Alessio Maria Monteleone ${ }^{88}$, MD, Markus M Nöthen ${ }^{47}$, MD, Tomas Novak ${ }^{97}, \mathrm{PhD}$, John $\mathrm{J}$ Nurnberger ${ }^{98}, \mathrm{MD}, \mathrm{PhD}$, Niamh O'Brien ${ }^{6}, \mathrm{PhD}$, Kevin S. O'Connell ${ }^{28,29}, \mathrm{PhD}$, Claire O'Donovan ${ }^{99,100}, \mathrm{MB}$ BchBAO, Michael C O'Donovan ${ }^{54}$, PhD, MD, Nils Ope ${ }^{19}$, MD, Abigail Ortiz ${ }^{101,102}$, MSW, MPH, Michael J Owen ${ }^{54}$, PhD, MD, Erik Pålsson ${ }^{77}$, Carlos Pato ${ }^{84}, \mathrm{MD}, \mathrm{PhD}$, Michele T Pato ${ }^{84}, \mathrm{MD}$, Joanna Pawlak ${ }^{57}, \mathrm{PhD}, \mathrm{MD}$, Julia-Katharina Pfarr ${ }^{17}$, M.Sc., Claudia Pisanu ${ }^{103}, M D$, James B. Potash ${ }^{59}$, MD, Mark H Rapaport ${ }^{104}, M D$, Daniela Reich-Erkelenz ${ }^{1}$, M.A., Andreas Reif ${ }^{35}, \mathrm{MD}$, Eva Reininghaus ${ }^{40}, \mathrm{MD}$, PhD, Jonathan Repple $^{19},{ }^{19}$, Helène Richard-Lepourie ${ }^{33}$, MD, Marcella Rietsche ${ }^{21}$, MD, Kai Ringwald ${ }^{17}$, M.Sc., Gloria Roberts ${ }^{95}$, PhD, Guy Rouleau ${ }^{105,106}$, MD, PhD, FRCPC, FRSC, Sabrina Schaupp ${ }^{1}$, M.Sc., William A Scheftner ${ }^{107}$, MD, Simon Schmitt ${ }^{17}$, 
50 M.Sc., Peter R. Schofield ${ }^{65,66}$, PhD DSc, K Oliver Schubert ${ }^{50,108}$, MD, Eva C. 51 Schulte ${ }^{1,2}$, MD, PhD, Barbara Schweizer ${ }^{59}$, R.N., B.S., Fanny Senner ${ }^{1,2}$, MD, 52 Giovanni Severino ${ }^{103}$, MD, Sally Sharp ${ }^{6}, \mathrm{PhD}$, Claire Slaney ${ }^{68}$, RN, Olav B. 53 Smeland ${ }^{28,29}, \mathrm{MD}, \mathrm{PhD}$, Janet L Sobell ${ }^{109}, \mathrm{PhD}$, Alessio Squassina ${ }^{99,103}$, Ph.D. MSci, 54 Pavla Stopkova ${ }^{97}, \mathrm{PhD}$, John Strauss ${ }^{73,80,81}$, MD, Alfonso Tortorella ${ }^{110}$, PhD, Gustavo 55 Turecki $^{45,11}$, MD, PhD, Joanna Twarowska-Hauser ${ }^{57}$, MD, PhD, Marin Veldic ${ }^{56}$, MD, 56 Eduard Vieta ${ }^{39}, \mathrm{MD}, \mathrm{PhD}$, John B. Vincent ${ }^{73,80,81}$, PhD, Wei $\mathrm{Xu}^{112}, \mathrm{PhD}$, Clement C. 57 Zai $^{73,80,81,113,114}$, PhD, Peter P. Zandi ${ }^{59}$, M.H.S., M.P.H., Ph.D., Maria Del $58 Z^{2}{ }^{32,103}$, MD, Psychiatric Genomics Consortium (PGC) BD Working Group, International Consortium on Lithium Genetics (ConLiGen), Colombia-US Cross Disorder Collaboration in Psychiatric Genetics, Arianna Di Florio ${ }^{54}$, PhD, MD, Jordan W. Smoller ${ }^{115,116}$, MD, Sc.D., Joanna M. Biernacka ${ }^{56,117}$, PhD, Francis J. McMahon $^{118}$, MD, Martin Alda ${ }^{97,99}$, MD, Bertram Muller-Myhsok ${ }^{20}$, MD, Nikolaos Koutsouleris $^{2,20,119}$, MD, Peter Falkai ${ }^{2}$, MD, Nelson B. Freimer ${ }^{4,120}$, MD, Till F.M. Andlauer $^{121}$, PhD, ${ }^{+}$Thomas G Schulze ${ }^{1,21,30,122,123}, \mathrm{MD}^{+}$Roel A. Ophoff ${ }^{4,}{ }^{120,124}$, $65 \mathrm{PhD}^{+}$

66

\section{AFFILIATION LIST AT THE END OF THE MANUSCRIPT \\ * joint first authors \\ + joint last authors}

\section{Corresponding Authors:}

\section{Janos L. Kalman, MD}

Institute of Psychiatric Phenomics and Genomics (IPPG),

University Hospital, LMU Munich,

Nussbaumstr. 7.

D-80336 Munich, Germany

Tel: +4989440053403

Email: janos.kalman@med.uni-muenchen.de

Loes M. Olde Loohuis, PhD

Center for Neurobehavioral Genetics

Semel Institute for Neuroscience and Human Behavior, University of California Los Angeles,

760 Westwood Plaza,

CA 90095 Los Angeles, USA

Tel: +13107942723

Email: loldeloohuis@mednet.ucla.edu

Running title: The genetics of disease onset in Bipolar Disorder

Keywords: bipolar disorder, age at onset, polarity at onset, GWAS, polygenic score 
medRxiv preprint doi: https://doi.org/10.1101/2021.04.16.21251163; this version posted April 16, 2021. The copyright holder for this preprint (which was not certified by peer review) is the author/funder, who has granted medRxiv a license to display the preprint in perpetuity.

It is made available under a CC-BY-NC-ND 4.0 International license.

\section{Word count: 3711}


medRxiv preprint doi: https://doi.org/10.1101/2021.04.16.21251163; this version posted April 16, 2021. The copyright holder for this preprint

(which was not certified by peer review) is the author/funder, who has granted medRxiv a license to display the preprint in perpetuity.

It is made available under a CC-BY-NC-ND 4.0 International license.

\section{RELEVANCE STATEMENT:}

101

102 In the largest study to systematically characterize age at onset $(\mathrm{N}=12977)$ and

103 polarity at onset $(\mathrm{N}=6773)$ in bipolar disorder, we describe an association between

104 illness onset characteristics and indicators of severity, confirming their clinical

105 relevance. Our study shows that that early illness onset is associated with genetic

106 liability for a broad range of psychiatric disorders. However, we also highlight

107 systematic differences in age at onset across cohorts, continents, and phenotype

108 definitions. This heterogeneity results in reduced heritability and affects genetic

109 analyses, underscoring the need for the development of standardized phenotype

110 definitions.

111 
medRxiv preprint doi: https://doi.org/10.1101/2021.04.16.21251163; this version posted April 16, 2021. The copyright holder for this preprint

\section{Abstract}

113 Background: Studying the phenotypic and genetic characteristics of age and

114 polarity at onset (AAO, PAO) in bipolar disorder (BD) can provide new insights into

115 disease pathology and facilitate the development of screening tools.

116 Aims: To examine the genetic architecture of AAO and PAO and their association

117 with BD disease characteristics.

118 Methods: Genome-wide association studies (GWASs) and polygenic score (PGS)

119 analyses of $\mathrm{AAO}(\mathrm{N}=12977)$ and PAO $(\mathrm{N}=6773)$ were conducted in BD patients of

12034 cohorts and a replication sample $(\mathrm{N}=2237)$. The association of onset with disease

121 characteristics was investigated in two of these cohorts.

122 Results: Earlier AAO was associated with an increased risk of psychotic symptoms,

123 suicidality, and fewer episodes. A depressive onset correlated with lifetime suicidality

124 and a manic onset with delusions and manic episodes. Systematic differences in

125 AAO between cohorts and continents of origin were observed. This was also

126 reflected in SNV-based heritability estimates, with higher heritabilities for stricter

127 onset definitions. Increased polygenic scores for autism spectrum disorder $(\beta=-0.34$

128 years, $S E=0.08)$, major depression $(\beta=-0.34$ years, $S E=0.08)$, schizophrenia $(\beta=-$

1290.39 years, $S E=0.08)$, and educational attainment $(\beta=-0.31$ years, $S E=0.08)$ were

130 associated with an earlier AAO. The AAO GWAS identified one significant locus, but

131 this finding did not replicate. Neither GWAS nor PGS analyses yielded significant

132 associations with PAO.

133 Conclusions: $\mathrm{AAO}$ and PAO are associated with indicators of $\mathrm{BD}$ severity.

134 Individuals with an earlier onset show an increased polygenic liability for a broad

135 spectrum of psychiatric traits. Systematic differences in AAO across cohorts,

136 continents, and phenotype definitions introduce significant heterogeneity, affecting

137 analyses. 
medRxiv preprint doi: https://doi.org/10.1101/2021.04.16.21251163; this version posted April 16, 2021. The copyright holder for this preprint (which was not certified by peer review) is the author/funder, who has granted medRxiv a license to display the preprint in perpetuity.

\author{
It is made available under a CC-BY-NC-ND 4.0 International license.
}

138 
medRxiv preprint doi: https://doi.org/10.1101/2021.04.16.21251163; this version posted April 16, 2021. The copyright holder for this preprint (which was not certified by peer review) is the author/funder, who has granted medRxiv a license to display the preprint in perpetuity.

\section{MAIN TEXT}

\section{1. Introduction}

141 Bipolar disorder (BD) is highly heritable and affects approximately $1 \%$ of the

142 population (1). It has a recurrent or chronic course and is associated with

143 psychosocial impairment and reduced functioning, and it is a leading cause of global

144 disease burden (2,3). Individuals usually experience their first (hypo)manic or

145 depressive episode of BD in adolescence or early adulthood, but often they are not

146 diagnosed until five to ten years later (4), especially in case of earlier age at onset or

147 a depressive index episode (5). Early illness onset is associated with a more severe

148 disease course and greater impairment across a wide range of mental and physical

149 disorders and is a useful prognostic marker (6-9). However, pathophysiological

150 processes leading to a disorder are thought to begin long before the first symptoms

151 appear $(10,11)$. Investigating the factors contributing to age and polarity (i.e., either a

152 (hypo)manic or depressive episode) at onset could thus improve our understanding

153 of disease pathophysiology and facilitate development of personalized screening and

154 preventive measures. Accordingly, age and polarity at BD onset are considered as

155 suitable phenotypes for genetic analyses. Genome-wide association studies

156 (GWASs) have improved our understanding of the genetic architecture of

157 susceptibility to BD; however, the genetic determinants of age and polarity at onset

158 remain largely unknown. Evidence suggests that patients with an early age at onset

159 carry a stronger genetic loading for BD risk (12). For example, an earlier parental

160 age at onset increases familial risk for BD and is one of the strongest predictors of 5-

161 year illness onset in affected offspring (12-14). Thus far, GWASs for age at BD

162 onset have been underpowered (15-17), and a study on 8610 cases found no

163 significant evidence for a heritable component contributing to onset age (16). 
medRxiv preprint doi: https://doi.org/10.1101/2021.04.16.21251163; this version posted April 16, 2021. The copyright holder for this preprint

164 Previous research suggested that a higher genetic risk burden for schizophrenia 165 (SZ) may be associated with earlier age at onset of BD (16), but this finding was not 166 replicated (18-20). Moreover, a recent study did not find an association of BD PGS 167 with age at onset (21). Polarity of onset was shown to cluster in families (22), but the 168 genetic architecture of polarity at onset has not yet been investigated. To fill these 169 knowledge gaps, we performed comprehensive analyses of age and polarity at BD 170 onset in the largest sample studied to date by (i) examining phenotype definitions 171 and associations, (ii) conducting systematic GWASs, and (iii) investigating whether 172 genetic load for neuropsychiatric disorders and traits contributes to age and polarity 173 at BD onset.

\section{2. Methods}

\section{2.1. Sample for the discovery GWAS}

176 Participants with a BD diagnosis and age at onset information were selected from

177 independent datasets, including those previously submitted to the Psychiatric

178 Genomics Consortium (PGC) BD Working Group $(18,23)$ and the International

179 Consortium on Lithium Genetics (ConLiGen) (24). These consortia aggregate data 180 from many cohorts worldwide. Our analyses comprised 34 cohorts with 12977 BD

181 European ancestry cases from Europe, North America, and Australia. For a 182 description of sample ascertainment, see the Supplementary Material. The authors 183 assert that all procedures contributing to this work comply with the ethical standards

184 of the relevant national and institutional committees on human experimentation and 185 with the Helsinki Declaration of 1975, as revised in 2008. All procedures involving 186 human subjects/patients were approved by the local ethics committees, and written 187 informed consent was obtained from all subjects/patients. 
medRxiv preprint doi: https://doi.org/10.1101/2021.04.16.21251163; this version posted April 16, 2021. The copyright holder for this preprint

2.1.1. Definition of age at onset

189 The definition of age at BD onset differed by cohort. To enhance cross-cohort

190 comparability, we grouped the definitions into four broad categories (Supplementary

191 Table S1): (1) Diagnostic interview: age at which the patient first experienced a

192 (hypo)manic, mixed, or major depressive episode according to a standardized

193 diagnostic interview; (2) Impairment/help-seeking: age at which symptoms began to

194 cause subjective distress or impaired functioning or at which the patient first sought

195 psychiatric treatment; (3) Pharmacotherapy: age at first administration of medication;

196 (4) Mixed: a combination of the above-mentioned definitions. Across definitions,

197 participants younger than eight years at onset were excluded $(n=279)$ because of the

198 uncertainty about the reliability of retrospective recall of early childhood onset.

199 The distribution of age at onset was highly skewed and differed greatly across

200 the cohorts (Table 1 and Fig. 1). Therefore, we transformed age at onset in each

201 cohort by rank-based inverse normal transformation and used this normalized

202 variable as the primary dependent variable in all genetic analyses. To facilitate

203 interpretability of effect sizes, we also report results of the corresponding

204 untransformed age at onset.

205 2.1.2. Definition of polarity at onset

206 For each cohort, polarity at onset was defined by comparing the age at the first

207 (hypo)manic and first depressive episode or using the polarity variable provided by

208 the cohort. Specifically, patients were divided into three subgroups: (1) (hypo)mania

209 before depression (PAO-M), (2) depression before (hypo)mania (PAO-D), and (3)

210 mixed (PAO-X). The third category included patients with mixed episodes and those

211 with a first (hypo)manic and depressive episode within the same year (Table 1). In

212 the primary analysis, we combined (hypo)mania and mixed onset cases and 
medRxiv preprint doi: https://doi.org/10.1101/2021.04.16.21251163; this version posted April 16, 2021. The copyright holder for this preprint (which was not certified by peer review) is the author/funder, who has granted medRxiv a license to display the preprint in perpetuity.

It is made available under a CC-BY-NC-ND 4.0 International license .

213 assigned this as the reference category. In secondary analyses, we excluded the

214 mixed cases.

215 2.2. Disease characteristics

216 We performed phenotypic analyses of disease onset in BD type I patients from three

217 cohorts: the Dutch Bipolar cohort $(\mathrm{N}=1313)$ (25) and the German PsyCourse (26)

218 and FOR2107 (27) cohorts, which were analyzed jointly ( $\mathrm{N}=346)$. We analyzed the

219 following disease characteristics, which were previously reported as being

220 associated with disease onset and were assessed in a similar way across cohorts

221 (28): lifetime delusions, lifetime hallucinations, history of suicide attempt, suicidal

222 ideation, current smoking, educational attainment, living together with a partner, and

223 frequency of manic and depressive episodes per year. For more detailed

224 information, see the Supplementary Material and Supplementary Table S9.

\section{2.3. Genetic analyses}

226 We analyzed age at onset in 34 cohorts comprising 12977 BD patients. We

227 performed a GWAS on these cohorts and attempted to replicate any findings in a

228 GWAS on six additional cohorts with 2237 BD patients. For details on the datasets,

229 including phenotype definitions and distributions, see Table 1, Fig. 1, and

230 Supplementary Table S1.

231 2.3.1. Genotype data quality control and imputation

232 Cohorts were genotyped according to local protocols. Individual genotype data of all

233 discovery-stage cohorts were processed with the PGC Rapid Imputation

234 and Computational Pipeline for GWAS (RICOPILI) (29) with the default parameters

235 for standardized quality control (QC), imputation, and analysis. Before imputation,

236 filters for the removal of variants included non-autosomal chromosomes, 
medRxiv preprint doi: https://doi.org/10.1101/2021.04.16.21251163; this version posted April 16, 2021. The copyright holder for this preprint

237 missingness $\geq 0.02$, and a Hardy-Weinberg equilibrium test $P<1 \times 10^{-10}$. Individuals

238 were removed if they showed a genotyping rate $\leq 0.98$, absolute deviation in

239 autosomal heterozygosity of $F_{\text {het }} \geq 0.2$, or a deviation $>4$ SDs from the mean in any of

240 the first eight multidimensional scaling (MDS) ancestry components within each

241 cohort. From genetic duplicates (assessed with the genetic identity-by-state matrix)

242 and relatives (pi-hat >0.2) across all samples, only the case with more complete

243 phenotypic information on AAO and PAO, sex, and diagnosis was retained.

244 Imputation was performed by IMPUTE2 with the Haplotype Reference Consortium

245 reference panel (30).

246 2.3.2. Genome-wide association studies

247 We conducted separate GWASs for all cohorts containing 40 or more individuals in

248 RICOPILI/PLINK (29,31), with sex, BD subtype, and the first eight ancestry

249 components as covariates. Sample sizes are provided in Supplementary Tables S2,

250 S7. The results showed no inflation of test statistics (Supplementary Table S2). We

251 combined the GWASs in METAL by fixed-effects meta-analysis (32). The primary

252 analyses were transformed age at onset (analyzed by linear regression), and polarity

253 at onset (analyzed by logistic regression). Secondary analyses included GWASs

254 stratified by age at onset definition and continent of origin.

255 For the meta-analysis summary statistics, we applied the following variant-level post-

256 QC parameters: imputation INFO score $\square \geq 0.9, \quad$ MAF $\square \geq 0.05$, and successfully

$257 \mathrm{imputed} /$ genotyped in $\square$ more than $\square$ half of the cohorts.

258 We estimated power to replicate our original GWAS finding using the pwr package in

259 R. Given the parameters from the locus identified through our discovery GWAS (beta

$260=0.075$, allele frequency $=0.32$ ) and a standardized phenotype, we had $76 \%$ power 
medRxiv preprint doi: https://doi.org/10.1101/2021.04.16.21251163; this version posted April 16, 2021. The copyright holder for this preprint (which was not certified by peer review) is the author/funder, who has granted medRxiv a license to display the preprint in perpetuity.

It is made available under a CC-BY-NC-ND 4.0 International license .

261 to detect the effect in our sample size of 2237 at an alpha level of 0.1 . For

262 comparison, we had $57 \%$ power to detect the effect in our discovery sample.

263 2.3.3. Polygenic Scoring

264 We calculated polygenic scores (PGS) based on prior GWAS of Attention-

265 Deficit/Hyperactivity Disorder (ADHD) (33), Autism Spectrum Disorder (ASD) (34),

266 BD (18), Educational Attainment (EA, measured as “years in education") (35), Major

267 Depression (MD) (36), and schizophrenia (37) (Supplementary Table S3). PGS

268 weights were estimated with PRS-CS (38), with six scores per genome-wide

269 association study (GWAS; with $\varphi=1 \times 10^{-1}, 1 \times 10^{-2}, 1 \times 10^{-3}, 1 \times 10^{-4}, 1 \times 10^{-5}$, and

$\left.2701 \times 10^{-6}\right)$. We tested the associations of the PGS with the AAO and PAO by linear and

271 logistic regressions, respectively, with the same covariates as in the GWAS

272 analyses. The significance threshold was Bonferroni-corrected for 96 tests ( $\alpha$

$273=\square 0.05 /[6 \varphi$ thresholds $\times 8$ traits $\times 2$ phenotypes $\left.]=5.2 \times 10^{-4}\right)$.

274 2.3.3. Heritability analyses

275 We assessed the variance in age and polarity at onset explained by genotyped

276 variants (single-nucleotide variant [SNV]-based heritability, $h^{2}{ }_{S N V}$ ). For individual

277 cohorts with more than 1000 samples, we estimated $h^{2}$ SNV with GCTA GREML

$278(39,40)$. Here, we validated the robustness of the $h^{2}$ SNV estimate with the mean of

$2791000 \times$ resampling of $95 \%$ of the sample. For meta-analysis summary statistics with

280 sample sizes $>3000$, we estimated $h_{S N V}^{2}$ by linkage disequilibrium (LD) score

281 regression (41). The $95 \%$ Cls were constrained to a minimum of 0 and a maximum 282 of 1.

\section{3. Results}

284 3.1. Heterogeneity of age and polarity at onset across cohorts 
medRxiv preprint doi: https://doi.org/10.1101/2021.04.16.21251163; this version posted April 16, 2021. The copyright holder for this preprint

285 Among the four definitions of age at onset across the 34 cohorts, impairment/help286 seeking was the most common in Europe and diagnostic interview the most common 287 in North America (Table 1, Fig. 1A-B). Across cohorts, the median age at onset was 28821 years (range of medians: 16-30 years; Fig. 1A-B). The median untransformed age 289 at onset differed significantly between BD subtypes (type I, 21 years; type II, 22 290 years; Kruskal-Wallis test $P=1.8 \times 10^{-4}$; Supplementary Table S6), age at onset 291 definitions (diagnostic interview, 19 years; impairment/help-seeking, 23 years; 292 pharmacotherapy, 30 years; mixed, 22 years; $P=2.96 \times 10^{-191}$ ), and continent of origin

293 (Europe, 24 years; North America, 18 years; and Australia, 19.5 years; $P=2.0 \times 10^{-}$

$294{ }^{263}$ ). These differences across continents remained significant when including onset 295 definitions and BD subtype in a multivariable regression model, indicating that they 296 are not entirely driven by differences between diagnostic instruments 297 (Supplementary Table S6).

298 The majority of patients had a depression-first polarity at onset in both Europe and 299 North America (57\% and 59\%, respectively; $P=0.17$ test of proportion). Depression300 first cases were less frequent in the impairment/help-seeking than in the diagnostic 301 interview category (55\% and $60 \%$, respectively; $P=4.5 \times 10^{-4}$, Supplementary Fig. S1). SUGGESTED POSITION OF TABLE 1 and FIGURE 1

\section{3.2. Analyses of disease characteristics}

305 In a meta-analysis of the Dutch and German samples, earlier age at onset was

306 significantly associated with a higher probability of lifetime delusions, hallucinations,

307 suicide attempts, suicidal ideation, lower educational attainment, and not living

308 together (Table 2, Supplementary Tables S4 and S5). Later age at onset was 309 positively significantly correlated with a higher number of manic and depressive 
medRxiv preprint doi: https://doi.org/10.1101/2021.04.16.21251163; this version posted April 16, 2021. The copyright holder for this preprint

(which was not certified by peer review) is the author/funder, who has granted medRxiv a license to display the preprint in perpetuity.

It is made available under a CC-BY-NC-ND 4.0 International license .

310 episodes per year (see secondary analyses in the Supplementary Material).

311 Moreover, a (hypo)manic onset was significantly associated with a greater likelihood

312 of delusions and more manic episodes per year, whereas a depressive onset was

313 associated with a higher probability of suicidal ideation and lifetime suicide attempts.

\subsection{Genome-wide association studies}

317 In our GWAS meta-analysis of age at onset using all 34 cohorts, one locus reached

318 genome-wide significance (rs1610275 on chromosome 16; minor allele G

319 frequency $=0.319, \beta=0.075 \mathrm{SDs}, \mathrm{SE}=0.014, P=3.39 \times 10^{-8}$, Fig. $2 A$, Supplementary

320 Table S7, Supplementary Fig. S2). This SNV mapped to an intron of the brain-

321 expressed gene FTO (alpha-ketoglutarate dependent dioxygenase, Fig. 2B).

322 However, this association was not replicated in an independent sample of six cohorts

323 (Supplementary Table S7, Supplementary Fig. S2). In this replication sample

$324(\mathrm{~N}=2237)$, we had $76 \%$ power to replicate this SNV at $P=0.1$.

325 In the GWAS of polarity at onset, no variant was genome-wide significant in either

326 primary (PAO-M/-X vs PAO-D) or secondary (PAO-M vs PAO-D) analyses

327 (Supplementary Fig. S3).

328 We calculated PGSs for age and polarity at onset using leave-one-out summary 329 statistics from these GWASs. The age-at-onset PGS was nominally significantly 330 associated with age at onset $(\beta=0.23$ years, $\mathrm{SE}=0.08, P=0.0087, \varphi=0.1, F i g .2 C-D)$

331 for five of six tested $\varphi$ parameters but did not withstand correction for multiple testing 332 (Supplementary Table S8). The polarity-at-onset PGS was not associated with the 333 polarity at onset (Supplementary Fig. S4). 
medRxiv preprint doi: https://doi.org/10.1101/2021.04.16.21251163; this version posted April 16, 2021. The copyright holder for this preprint

\section{3.4. SNV-based heritability of the investigated phenotypes}

336 Using the GWAS summary statistics, we estimated the SNV-based heritability $h^{2}{ }_{S N V}$

337 by LD score regression (Fig. 1C). We estimated $h^{2}{ }_{S N V}$ directly from genotype data in

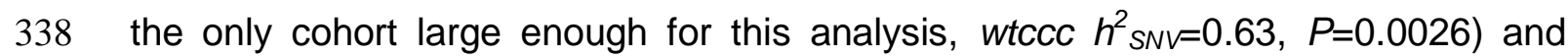

339 validated the robustness of this estimate by resampling $\left(h^{2}{ }_{S N V}=0.62\right.$, resampling $95 \%$

$340 \mathrm{Cl}=0.15-1.00)$. The $h_{S N V}^{2}$ estimates decreased when cohorts, phenotype definitions,

341 and continents were combined (e.g., "diagnostic interview" in North America:

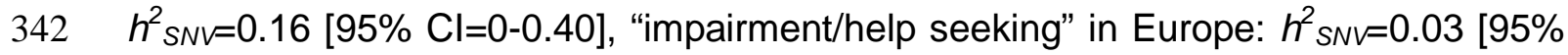

$343 \mathrm{Cl}=0-0.25]$, all combined $\left.h_{S N V=0.05}^{2}[95 \% \mathrm{Cl}=0-0.12]\right)$. Because the sample sizes

344 were smaller, we could not estimate the $h^{2}$ SNV of impairment/help seeking in North

345 America and diagnostic interview in Europe. For depressed vs. (hypo)manic and

346 mixed polarity at onset, $h^{2}$ SNV was $0.17(95 \% \mathrm{Cl}=0.05-0.29)$ on the observed scale.

\section{3.5. Associations of PGSs with age and polarity at onset}

348 We analyzed whether PGSs for five psychiatric disorders and EA were associated

349 with earlier age at onset (Fig. 2C-D, Supplementary Table S8). After correcting for 96

350 tests, higher PGSs for ASD ( $\beta=-0.34$ years per 1 SD increase in PGS, SE=0.08,

$\left.351 P=9.85 \times 10^{-6}\right), \quad \mathrm{MD} \quad\left(\beta=-0.34, \quad S E=0.08, \quad P=1.40 \times 10^{-6}\right), \quad S Z \quad(\beta=-0.39, \quad S E=0.08$,

$\left.352 P=2.91 \times 10^{-6}\right)$, and $\mathrm{EA}\left(\beta=-0.31, \mathrm{SE}=0.08, P=5.58 \times 10^{-5}\right)$ were significantly associated

353 with an earlier BD age at onset. This was not the case for ADHD or BD PGS. No

354 PGS was significantly associated with polarity at onset (Supplementary Fig. S4,

355 Supplementary Table S8).

\section{4. Discussion}

Our study represents the largest and most comprehensive characterization of

358 disease onset in BD to date. It highlights the clinical relevance of age and polarity at 
medRxiv preprint doi: https://doi.org/10.1101/2021.04.16.21251163; this version posted April 16, 2021. The copyright holder for this preprint

359 onset in BD by demonstrating how these phenotypes are associated with several

360 indicators of illness severity. We found that higher PGS for ASD, MD, SZ, and EA

361 were associated with an earlier age at onset. Thereby we demonstrated that the BD

362 age at onset has a polygenic etiology. Individuals with an earlier age at onset harbor

363 increased genetic liability for a broad spectrum of psychiatric disorders and related

364 traits. However, we show significant heterogeneity of age at onset (and, partly,

365 polarity at onset) across cohorts, continents, and age-at-onset definitions and

366 demonstrate the challenges for genetic analyses that occur in the presence of

367 substantial phenotypic heterogeneity. First, heritability estimates differed for criteria

368 used to define age at onset and decreased when combining multiple cohorts.

369 Second, a single genome-wide significant variant, identified in the age-at-onset

370 discovery GWAS, did not replicate in an independent dataset.

371 A striking finding of our study was the systematic difference in the age at

372 onset distribution across cohorts, continents, and assessment strategies. The

373 definition of age at onset correlated strongly with the continent, with diagnostic

374 interview being mainly used in North America and impairment/help-seeking in

375 Europe. Using multivariable regression, we showed that the continent-level

376 differences cannot fully be explained by the age-at-onset assessment strategy and

377 that both factors contribute significantly to the heterogeneity (Supplementary Table

378 S6) (4). However, variations in the demographic structure of analyzed populations

379 may have biased the assessed age at onset of $\mathrm{BD}$, contributing to the observed

380 differences (42). Although prior research has identified age at onset differences

381 across continents (e.g., the incidence of early onset BD is higher in the US than in

382 Europe $(43,44))$, this study is the first to systematically assess this heterogeneity 
medRxiv preprint doi: https://doi.org/10.1101/2021.04.16.21251163; this version posted April 16, 2021. The copyright holder for this preprint

383 across many cohorts with different ascertainment strategies and demonstrate how it 384 may reduce statistical power in genetic analyses.

385 Interestingly, these systematic differences in age at onset phenotypes are

386 reflected in heritability estimates: We observed the highest SNV-based heritability

$387 h_{\text {SNV }}^{2}$ when onset was established by diagnostic interview and the lowest when it

388 was captured with more health system-specific and subjective measurements, such

389 as item 4 of the Operational Criteria Checklist for Psychotic Illness (impairment/help-

390 seeking). Moreover, $h_{S N V}^{2}$ estimates approached zero when all samples were

391 combined in our primary analysis $\left(\mathrm{h}_{\mathrm{SNV}}^{2}=0.05 ; 95 \% \mathrm{Cl}=0-0.12\right)$, underscoring the

392 strong impact of phenotypic heterogeneity. Thus, we not only showed systematic

393 heterogeneity in a clinically relevant psychiatric phenotype across cohorts but also

394 provided direct evidence for how this heterogeneity can hamper genetic studies.

395 Notably, a recent investigation demonstrated that the phenotyping method (e.g.,

396 diagnostic interview vs. self-report) significantly influenced heritability estimates,

397 GWAS results, and PGS performance in analyses of MD susceptibility, with broader

398 phenotype definitions resulting in lower heritability estimates (45). Nevertheless, the

399 significant results in our PGS association analyses confirmed that a significant

400 genetic component of age at onset exists.

$401 \quad$ For polarity at disease onset, the relative proportion of patients reporting a

402 depressive index episode did not differ across continents but did differ across

403 instruments, i.e., a (hypo)manic onset was more common if age at onset was based

404 on impairment/help-seeking instead of diagnostic interview.

405 Although our discovery GWAS identified a genome-wide significant locus for 406 age at onset, the lack of replication suggests that this finding may have been a false-

407 positive. Of note, our replication power analysis did not account for the phenotypic 
medRxiv preprint doi: https://doi.org/10.1101/2021.04.16.21251163; this version posted April 16, 2021. The copyright holder for this preprint

408 and genetic heterogeneity across the cohorts and may thus have underestimated the 409 necessary sample size. Moreover, the replication sample was more ethnically

410 diverse than the discovery sample, reducing statistical power. While the effect of the

411 age at onset PGS on the trait measure itself was substantial $(0.23$ years per 1 SD

412 change in the PGS), the association was only nominally significant.

413 Possibly, the rank-based inverse-normal transformation of the age at onset

414 affected the GWAS and heritability analyses. We conducted this transformation

415 because, first, the original age at onset distribution was highly skewed and thus not

416 suitable for linear regression and, second, the age at onset differed significantly

417 between cohorts, which could have biased the meta-analysis. By transforming the

418 data, however, only the rank and not the absolute differences in onset between

419 patients was maintained, reducing interpretability of the phenotype and the genetic 420 effects.

421 Higher PGSs for SZ, MD, ASD, and EA were significantly associated with a 422 lower age at onset, confirming a genetic component for age at onset. This finding 423 supports the hypothesis that earlier age of onset, in addition to potentially being 424 driven by onset-specific modifier genes, is influenced by a transdiagnostic liability for 425 psychiatric disorders. In contrast to several other disorders (e.g. multiple sclerosis 426 and late-onset Alzheimer's disease), where the strongest genetic risk factors for 427 disease liability were also the most important genetic factors associated with earlier 428 disease onset $(8,46)$, we did not find a significant association between BD PGS and 429 age at BD onset, confirming a previous study (21). Importantly, the sample sizes of 430 both the SZ and MD GWASs were larger than those of the BD GWAS, improving the 431 predictive power of these PGSs compared to the BD PGS. 
medRxiv preprint doi: https://doi.org/10.1101/2021.04.16.21251163; this version posted April 16, 2021. The copyright holder for this preprint

432 Our finding of a significant relationship of higher EA PGS with an earlier age

433 at onset may seem counterintuitive. However, several studies found a significant

434 association between higher $\mathrm{EA}$ and $\mathrm{BD}(47,48)$. In addition, a recent study

435 demonstrated a positive genetic correlation and causal relationship between high EA

436 and $B D(49)$. Our findings show that high $E A$ is not only a risk factor for BD but is

437 also associated with an earlier onset.

$438 \quad$ In our analyses of polarity at onset, the small sample size and dichotomous

439 phenotype reduced statistical power. None of the tested PGSs were significantly

440 associated with polarity at onset, and the GWAS did not identify genome-wide

441 significant loci. However, we observed significant $h_{S N V}^{2}$ estimates for PAO-M/-X vs.

442 PAO-D, providing substantial evidence that genetic factors contribute to the polarity

443 at BD onset.

444 The success of GWASs in the study of complex, polygenic traits relies on ever

445 larger sample sizes and harmonized phenotype definitions and analysis techniques

446 (50). As previously shown for depression (45), our study suggests that heterogeneity

447 of phenotype definitions decreases the ability to identify genetic risk profiles that

448 contribute to clinically relevant BD phenotypes. In addition to phenotype definitions,

449 other factors that may limit cross-cohort comparability of the assessed phenotypes

450 include demographic differences, cultural differences in diagnostic practice, and the

451 uncertainty and measurement errors associated with recall bias, limited interrater

452 reliability, and differences across health care systems (43,51-53). In our study, we

453 performed both SNV-level and risk score associations using a structured meta-

454 analysis, which mitigates some of the noise introduced by phenotypic heterogeneity.

455 However, we are unable to account for differences in underlying genetic etiology of 
medRxiv preprint doi: https://doi.org/10.1101/2021.04.16.21251163; this version posted April 16, 2021. The copyright holder for this preprint

456 the phenotypes across cohorts. This heterogeneity is an important limitation of our

457 study and should be considered in future phenotype analyses.

$458 \quad$ Our phenotype analyses confirmed the clinical relevance of disease onset

459 phenotypes in BD. Age at BD onset was associated with important illness severity

460 indicators, such as suicidality, positive symptoms, and achieving a lower level of

461 education, thereby replicating findings of previous studies $(25,28,54)$. Furthermore,

462 patients with a depressive BD onset had an increased probability of lifetime

463 suicidality, while those with a (hypo)manic onset were more likely to experience

464 delusions and manic episodes (55-57). Contrary to previous evidence in a US (but

465 not a French) sample, we observed that an earlier onset was associated with fewer

466 episodes per illness year (56). Of note, when not normalizing for the illness duration,

467 the age at onset was positively correlated with the number of episodes.

468 4.1. Conclusion

469 Phenotypes of BD onset are clinically important trait measures that represent

470 the well-known clinical and biological heterogeneity of this severe psychiatric

471 disorder. Genetic analysis of age and polarity at onset may lead to a better

472 understanding of the biological risk factors underlying mental illness and support

473 clinical assessment and prediction. Our study provides significant evidence of a

474 genetic contribution to age and polarity at BD onset but also demonstrates the need

475 for systematic harmonization of clinical data on BD onset in future studies. The

476 coordinated efforts of international consortia and our growing ability to harness the

477 rich phenotypic information stored in electronic health records will provide an

478 unprecedented pool of phenotypic information on an increasingly diverse patient

479 population (58-60). We expect that future genetic studies of age and polarity at 
medRxiv preprint doi: https://doi.org/10.1101/2021.04.16.21251163; this version posted April 16, 2021. The copyright holder for this preprint

(which was not certified by peer review) is the author/funder, who has granted medRxiv a license to display the preprint in perpetuity.

It is made available under a CC-BY-NC-ND 4.0 International license .

480 onset will make major contributions toward our understanding of the etiology of BD

481 and other psychiatric disorders.

482

483

484

485

486 5. Author contributions

487 Concept and design: Kalman, Olde Loohuis, Vreeker, Andlauer, Schulze, and

488 Ophoff. Analysis and interpretation of data: Kalman, Olde Loohuis, Vreeker,

489 Andlauer

490 Drafting of the manuscript: Kalman, Olde Loohuis, Vreeker, Andlauer

491 Supervision, and critical revision of the manuscript: Schulze, Ophoff, McMahon,

492 Smoller, Alda.

493 All other authors provided data, contributed ideas and suggestions for analyses,

494 interpreted results and revised the final manuscript.

495

496 6. Acknowledgments

497 The authors thank Jacquie Klesing, Board-certified Editor in the Life Sciences (ELS),

498 for editing assistance with the manuscript.

499 BOMA-Australia sample: We thank Gin Mahli, Colleen Loo, and Micheal Breaskpear

500 for their contribution to clinical assessments of a subset of patients and also Andrew

501 Frankland for his work in collating clinical record data. 
medRxiv preprint doi: https://doi.org/10.1101/2021.04.16.21251163; this version posted April 16, 2021. The copyright holder for this preprint

(which was not certified by peer review) is the author/funder, who has granted medRxiv a license to display the preprint in perpetuity.

It is made available under a CC-BY-NC-ND 4.0 International license.

502 WTCCC sample: This study makes use of data generated by the Wellcome Trust

503 Case-Control Consortium. A full list of the investigators who contributed to the

504 generation of the data is available from www.wtccc.org.uk.

505 French sample: We thank the psychiatrists and psychologists who participated in the

506 clinical assessment of patients in France (C. Henry, S. Gard, JP Kahn, L Zanouy, RF

507 Cohen and O. Wajsbrot-Elgrabli) and thank the patients for their participation.

508 
medRxiv preprint doi: https://doi.org/10.1101/2021.04.16.21251163; this version posted April 16, 2021. The copyright holder for this preprint

(which was not certified by peer review) is the author/funder, who has granted medRxiv a license to display the preprint in perpetuity.

It is made available under a CC-BY-NC-ND 4.0 International license .

\section{7. Funding}

510 Loes M. Olde Loohuis: NIH K99/R00 MH116115.

511 Eli Stahl: NIH U01MH109536; E.S. is now employed by the Regeneron Genetics

512 Center.

513 Andrew McQuillin: Medical Research Council, Grant/Award Numbers: G0500791,

514 G0701007, G0801038, G1000708, G9623693N; Stanley Center for Psychiatric

515 Research at the Broad Institute

516 Douglas Ruderfer: R01MH116269

517 Maria Grigoroiu-Serbanescu: UEFISCDI, Romania, several grants

518 Tim B Bigdeli: NIH MH085548, MH085542, MH104564

519 Fabian Streit: BMBF grant 01EW1810 ERA-Net Neuron "Synschiz", BMBF grant

520 01ZX1614G e:Med Integrament

521 Mark J Adams: Wellcome Trust 104036/Z/14/Z, MRC MC_PC_17209

522 Rolf Adolfsson: Swedish Research Council (2009-33891-68296-196) and the

523 Swedish Federal Government under the LUA/ALF agreement (ALF; RV-161691)

524 Ole A. Andreassen: Norwegian Research Council, KG Jebsen Stiftelsen, South-

525 Eastern Norway Health Authority

526 Ceylan Balaban: BMBF "BipoLife" Subproject TPP1

527 Frank Bellivier: INSERM (Institut National de la Sante et de la Recherche Medicale -

528 C0829), AP-HP (Assistance Publique des Hopitaux de Paris - RBM0436), Fondation

529 FondaMental (RTRS Sante Mentale), Labex Bio-PSY (Investissements dAvenir

530 program managed by the ANR under reference ANR-11-IDEX-0004-02).

531 Antonio Benabarre: Thanks the support of the Spanish Ministry of Science and

532 Innovation (PI17/01122)

533 Wade Berrettini: R01 MH078156 
medRxiv preprint doi: https://doi.org/10.1101/2021.04.16.21251163; this version posted April 16, 2021. The copyright holder for this preprint (which was not certified by peer review) is the author/funder, who has granted medRxiv a license to display the preprint in perpetuity. It is made available under a CC-BY-NC-ND 4.0 International license .

534 Evelyn J Bromet: NIH MH085548, MH085542, MH104564

535 Sven Cichon: European Union Horizon 2020 Research and Innovation Programme

536 (grant 785907 (HBP SGA2)), BMBF grant 01ZX1314Ae:Med Integrament, Swiss

537 National Science Foundation (SNSF) grant 156791

538 William Coryell: R01 MH078154

539 Nick Craddock: Wellcome Trust (grant \#078901)

540 David Craig: R01 MH078159

541 Paul E. Croarkin: National Institue of Mental Health (NIMH) R01 MH113700

542 Udo Dannlowski: This work was funded by the German Research Foundation (DFG,

543 grant FOR2107 DA1151/5-1 and DA1151/5-2 to UD; SFB-TRR58, Projects C09 and

544 Z02 to UD) and the Interdisciplinary Center for Clinical Research (IZKF) of the

545 medical faculty of Munster (grant Dan3/012/17 to UD).

546 Franziska Degenhardt: German Federal Ministry of Education and Research (BMBF)

547 within the e:Med programme (grant COMMITMENT) and the EU COST (European

548 Cooperation in Science and Technology) programme (COST Action EnGagE

549 CA17130).

550 Bruno Etain: INSERM (Institut National de la Sante et de la Recherche Medicale -

551 C0829), AP-HP (Assistance Publique des Hopitaux de Paris - RBM0436), Fondation

552 FondaMental (RTRS Sante Mentale), Labex Bio-PSY (Investissements dAvenir

553 program managed by the ANR under reference ANR-11-IDEX-0004-02).

554 Ayman H Fanous: NIH MH085548, MH085542, MH104564

555 Janice M. Fullerton: National Health and Medical Research Council (Australia) grants

556 1037196,1063960, 1066177; and The Janette Mary ONeil Research Fellowship

557 Julie Garnham: Canadian Institutes of Health Research (grant \#166098); Dalhousie

558 Medical Research Foundation, Genome Atlantic, Lindsay family fund 
medRxiv preprint doi: https://doi.org/10.1101/2021.04.16.21251163; this version posted April 16, 2021. The copyright holder for this preprint (which was not certified by peer review) is the author/funder, who has granted medRxiv a license to display the preprint in perpetuity.

559 Elliot Gershon: R01 MH078153

560 Tim Hahn: TH was supported by the German Research Foundation (DFG grants

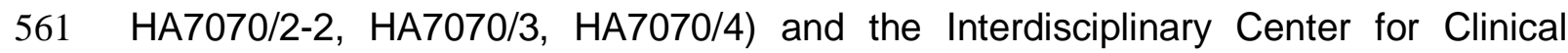

562 Research (IZKF) of the medical faculty of Munster (MzH3/020/20).

563 Stephane Jamain: INSERM (Institut National de la Sante et de la Recherche

564 Medicale - C0829), AP-HP (Assistance Publique des Hopitaux de Paris - RBM0436),

565 Fondation FondaMental (RTRS Sante Mentale), Labex Bio-PSY (Investissements

566 dAvenir program managed by the ANR under reference ANR-11-IDEX-0004-02).

567 Esther Jimenez: EJ thanks the support of the Spanish Ministry of Science and 568 Innovation (PI15/00283, PI18/00805) integrated into the Plan Nacional de I+D+I and

569 co-financed by the ISCIII-Subdireccin General de Evaluacin and the Fondo Europeo

570 de Desarrollo Regional (FEDER); the Instituto de Salud Carlos III; the CIBER of

571 Mental Health (CIBERSAM); the Secretaria dUniversitats i Recerca del Departament

572 dEconomia i Coneixement (2017 SGR 1365), the CERCA Programme, and the

573 Departament de Salut de la Generalitat de Catalunya for the PERIS grant

574 SLT006/17/00357.

575 lan Jones: Wellcome Trust (grant \#078901)

576 Lisa Jones: Wellcome Trust (grant \#078901)

577 John R. Kelsoe: R01 MH078151

578 Tilo Kircher: This work was funded by the German Research Foundation (DFG, grant

579 FOR2107 KI588/14-1 and FOR2107 KI588/14-2 to TK)

580 George Kirov: Recriutment of the Bulgarian Trios was funded by the Janssen

581 Research Foundation

582 James A Knowles: NIH MH085548, MH085542, MH104564

583 Thorsten Kranz: BMBF "BipoLife" Subproject TPP1 
medRxiv preprint doi: https://doi.org/10.1101/2021.04.16.21251163; this version posted April 16, 2021. The copyright holder for this preprint (which was not certified by peer review) is the author/funder, who has granted medRxiv a license to display the preprint in perpetuity. It is made available under a CC-BY-NC-ND 4.0 International license .

584 Trine Vik Lagerberg: Norwegian Research Council (grant \#288542)

585 Mikael Landen: The Stanley Center for Psychiatric Research, Broad Institute from a

586 grant from Stanley Medical Research Institute, the Swedish Research Council (2018-

587 02653), the Swedish foundation for Strategic Research (KF10-0039), the Swedish

588 Brain foundation (FO2020-0261), and the Swedish Federal Government under the

589 LUA/ALF agreement (ALF 20170019, ALFGBG-716801).

590 William Lawson: R01 MH078161

591 Marion Leboyer: INSERM (Institut National de la Sante et de la Recherche Medicale

592 - C0829), AP-HP (Assistance Publique des Hopitaux de Paris - RBM0436),

593 Fondation FondaMental (RTRS Sante Mentale), Labex Bio-PSY (Investissements

594 dAvenir program managed by the ANR under reference ANR-11-IDEX-0004-02).

595 Dolores MAlaspina: NIH MH085548, MH085542, MH104564

596 Melvin Mclnnis: R01 MH078162

597 Andrew M Mclntosh: Wellcome Trust 104036/Z/14/Z, MRC MC_PC_17209

598 Helena Medeiros: NIH MH085548, MH085542, MH104564

599 Ingrid Melle: "Regional Health Authority South-Eastern Norway (grants \#

600 2015088,2018093)"

601 Vihra Milanova: Recriutment of the Bulgarian Trios was funded by the Janssen

602 Research Foundation

603 Philip B. Mitchell: National Health and Medical Research Council (Australia) grants

6041037196,1177991

605 John Nurnberger: R01 MH078152

606 Carlos Pato: NIH MH085548, MH085542, MH104564

607 Michele T Pato: NIH MH085548, MH085542, MH104564

608 James B. Potash: R01 MH078157 
medRxiv preprint doi: https://doi.org/10.1101/2021.04.16.21251163; this version posted April 16, 2021. The copyright holder for this preprint (which was not certified by peer review) is the author/funder, who has granted medRxiv a license to display the preprint in perpetuity.

It is made available under a CC-BY-NC-ND 4.0 International license .

609 Mark H Rapaport: NIH MH085548, MH085542, MH104564

610 Andreas Reif: BMBF "BipoLife" Subproject TPP1

611 Marcella Rietschel: BMBF grant 01EW1810 ERA-Net Neuron "Synschiz", BMBF

612 grant 01EW1904 ERA-Net Neuron "Embed", BMBF grant 01ZX01909A e:Med

613 SysmedSUD, BMBF grant 01ZX1614G e:Med Integrament

614 Gloria Roberts: National Health and Medical Research Council (Australia) grants

6151037196

616 Guy Rouleau: Canadian Institutes of Health Research (grant \#166098)

617 William A. Scheftner: R01 MH078155

618 Peter R. Schofield: National Health and Medical Research Council (Australia) grants

$6191037196,1063960,1176716$

620 Janet L Sobell: NIH MH085548, MH085542, MH104564

621 John Strauss: Canadian Institutes of Health Research, MOP-172013

622 Gustavo Turecki: Canadian Institutes of Health Research (grant \#166098)

623 Eduard Vieta: EV thanks the support of the Spanish Ministry of Science and

624 Innovation (PI15/00283, PI18/00805) integrated into the Plan Nacional de I+D+I and

625 co-financed by the ISCIII-Subdireccin General de Evaluacin and the Fondo Europeo

626 de Desarrollo Regional (FEDER); the Instituto de Salud Carlos III; the CIBER of

627 Mental Health (CIBERSAM); the Secretaria dUniversitats i Recerca del Departament

628 dEconomia i Coneixement (2017 SGR 1365), the CERCA Programme, and the

629 Departament de Salut de la Generalitat de Catalunya for the PERIS grant

630 SLT006/17/00357.

631 John B. Vincent: Canadian Institutes of Health Research, MOP-172013

632 Jordan W Smoller: R01MH063445 
medRxiv preprint doi: https://doi.org/10.1101/2021.04.16.21251163; this version posted April 16, 2021. The copyright holder for this preprint

633 Francis J. McMahon: Funded in part by the Intramural Research Program of the

$634 \mathrm{NIMH}(\mathrm{ZIA} \mathrm{MH} 002843)$

635 Martin Alda: Canadian Institutes of Health Research (grant \#166098); Dalhousie

636 Medical Research Foundation, Genome Atlantic, Lindsay family fund

637 Till. F. M. Andlauer: German Federal Ministry of Education and Research (BMBF)

638 through the DIFUTURE consortium of the Medical Informatics Initiative Germany

639 (grant 01ZZ1804A) and the Integrated Network IntegraMent, under the auspices of

640 the e:Med Programme (grant 01ZX1614J), as well as the European Unions Horizon

6412020 Research and Innovation Programme (grant MultipleMS, EU RIA 733161)

642 The Collection of the Dutch cohort was funded through NIMH R01MH090553

643 awarded to Dr. Ophoff.

644 The collection of the Colombian samples was funded through NIMH R01 MH113078

645 awarded to Drs. Lopez-Jaramillo, Bearden and Freimer.

646 The collection of the BOMA-Australia sample (bip_bmau_eur) was supported by the

647 Australian National Medical and Health Research Council (NHMRC) Program Grant

6481037196 and Project Grants 1063960 and 1066177. DNA was extracted by Genetic

649 Repositories Australia, an Enabling Facility that was supported by NHMRC Enabling

650 Grant 401184. We gratefully acknowledge the Janette Mary ONeil Research

651 Fellowship (to JMF). We acknowledge support from NHMRC Investigator Grants

652 (Leadership 3) to PBM (1177991) and PRS (1176716).

653 Funding for the project was provided by the Wellcome Trust under award 076113,

$654 \quad 085475$ and 090355.

655 The work by the French group was supported by INSERM (Institut National de la

656 Sante et de la Recherche Medicale - C0829), AP-HP (Assistance Publique des

657 Hopitaux de Paris - RBM0436), the Fondation FondaMental (RTRS Sante Mentale), 
medRxiv preprint doi: https://doi.org/10.1101/2021.04.16.21251163; this version posted April 16, 2021. The copyright holder for this preprint (which was not certified by peer review) is the author/funder, who has granted medRxiv a license to display the preprint in perpetuity. It is made available under a CC-BY-NC-ND 4.0 International license.

658 and the labex Bio-PSY (Investissements dAvenir program managed by the ANR 659 under reference ANR-11-IDEX- 0004-02).

660 
medRxiv preprint doi: https://doi.org/10.1101/2021.04.16.21251163; this version posted April 16, 2021. The copyright holder for this preprint (which was not certified by peer review) is the author/funder, who has granted medRxiv a license to display the preprint in perpetuity.

It is made available under a CC-BY-NC-ND 4.0 International license .

\section{8. Declaration of Interest}

662 Amare T. Azmeraw: Dr Amare has received 2020-2022 NARSAD Young Investigator

663 Grant from the Brain \& Behaviour Research Foundation.

664 Ole A. Andreassen: Speaker's honorarium Sunovion, Lundbeck. Consultant 665 HealthLytix

666 Bernhard Baune: Honoraria: Lundbeck, Janssen, LivaNova, Servier

667 Carrie Bearden: Novartis Scientific Advisory Board

668 Clark Scott: Honoraria and Investigator Initiated project funding from Jannsen-Cilag

669 Australia, Lundbeck-Otsuka Australia

670 J. Raymond DePaulo: owns stock in CVS Health; JRD was unpaid consultant for

671 Myriad Neuroscience 2017 \& 2019

672 Michael C. O’Donovan: Research unrelated to this manuscript supported by a 673 collaborative research grant from Takeda Pharmaceuticals

674 Bruno Etain: Honoraria for Sanofi

675 Mark A. Frye: Grant Support Assurex Health, Mayo Foundation, Medibio Consultant

676 (Mayo) Actify Neurotherapies, Allergan, Intra-Cellular Therapies, Inc., Janssen,

677 Myriad, Neuralstem Inc., Sanofi, Takeda, Teva Pharmaceuticals

678 Per Hoffmann: Employee of Life\&Brain GmbH, Member of the Scientific Advisory

679 Board of HMG Systems Engeneering GmbH

680 Mikael Landen: Speaker's honoraria Lundbeck pharmaceuticals

681 Andrew M Mclntosh: Research funding from The Sackler Trust, speaker fees from

682 Illumina and Janssen

683 Philip B. Mitchell: Remuneration for lectures in China on bipolar disorder research by

684 Sanofi (Hangzhou)

685 John Nurnberger: Investigator for Janssen 
medRxiv preprint doi: https://doi.org/10.1101/2021.04.16.21251163; this version posted April 16, 2021. The copyright holder for this preprint

686 Benjamin M. Neale: Is a member of the scientific advisory board at Deep Genomics

687 and RBNC Therapeutics. A consultant for Camp4 Therapeutics, Takeda

688 Pharmaceutical and Biogen.

689 Andreas Reif: Speaker's honoraria / Advisory boards: Janssen, Shire/Takeda, 690 Medice, SAGE and Servier

691 Eli Stahl: now employed by the Regeneron Genetics Center.

692 Kato Tadafumi: Honoraria: Kyowa Hakko Kirin Co., Ltd., Eli Lilly Japan K.K., Otsuka

693 Pharmaceutical Co., Ltd., GlaxoSmithKline K.K., Taisho Pharma Co., Ltd., Taisho

694 Pharmaceutical Co., Ltd., Taisho Toyama Pharmaceutical Co., Ltd., Dainippon

695 Sumitomo Pharma Co., Ltd., Meiji Seika Pharma Co., Ltd., Pfizer Japan Inc.,

696 Mochida Pharmaceutical Co., Ltd., Shionogi \& Co., Ltd., Janssen Pharmaceutical

697 K.K., Janssen Asia Pacific, Yoshitomiyakuhin, Astellas Pharma Inc., Nippon

698 Boehringer Ingelheim Co. Ltd., MSD K.K., Kyowa Pharmaceutical Industry Co., Ltd.,

699 Takeda Pharmaceutical Co., Ltd., Mitsubishi Tanabe Pharma Corporation, Eisai Co.,

700 Ltd. Grants: Takeda Pharmaceutical Co., Ltd., Dainippon Sumitomo Pharma Co.,

701 Ltd., Otsuka Pharmaceutical Co., Ltd., Shionogi \& Co., Ltd., Eisai Co., Ltd.,

702 Mitsubishi Tanabe Pharma Corporation.

703 Eduard Vieta: Has received grants and served as consultant, advisor or CME

704 speaker for the following entities: AB-Biotics, Abbott, Allergan, Angelini, Dainippon

705 Sumitomo Pharma, Ferrer, Gedeon Richter, Janssen, Lundbeck, Otsuka, Sage,

706 Sanofi-Aventis, Sunovion, and Takeda.

707

708 None of the other Authors reported any biomedical financial interests or potential

709 conflicts of interest.

710 
medRxiv preprint doi: https://doi.org/10.1101/2021.04.16.21251163; this version posted April 16, 2021. The copyright holder for this preprint (which was not certified by peer review) is the author/funder, who has granted medRxiv a license to display the preprint in perpetuity. It is made available under a CC-BY-NC-ND 4.0 International license .

\section{Availability of results}

712 Summary statistics for our meta-analysis of the GWAS cohort samples are available

713 through the PGC (https://www.med.unc.edu/pgc/download-results/).

\section{Author details (affiliations)}

717

718

719

720

721

722

723

724

725

726

727

728

729

730

731

732

733

734

735

736

737

738

739

740

741

742

743

744

745

746

747

748

749

750

751

752

753

754

755
${ }^{1}$ Institute of Psychiatric Phenomics and Genomics (IPPG), University Hospital, LMU Munich, Munich, Germany

${ }^{2}$ Department of Psychiatry and Psychotherapy, University Hospital Munich

${ }^{3}$ International Max Planck Research School for Translational Psychiatry, Munich, Germany

${ }^{4}$ Center for Neurobehavioral Genetics, Semel Institute for Neuroscience and Human Behavior, University of California Los Angeles, Los Angeles, USA

${ }^{5}$ Department of Child and Adolescent Psychiatry and Psychology, Erasmus MC, The Netherlands

${ }_{7}^{6}$ Division of Psychiatry, University College London, London, GB

7 Division of Psychiatric Genomics, Mount Sinai School of Medicine, New York NY 10029 USA

8 Division of Genetic Medicine, Department of Medicine, Vanderbilt Genetics Institute, Vanderbilt University Medical Center

${ }^{9}$ Department of Biomedical Informatics, Vanderbilt University Medical Center

${ }^{10}$ Department of Psychiatry and Behavioral Sciences, Vanderbilt University Medical Center

${ }^{11}$ Alexandru Obregia Clinical Psychiatric Hospital, Bucharest, Romania

12 Department of Psychiatry and Psychotherapy, Charite - Universitätsmedizin

${ }^{13}$ Analytic and Translational Genetics Unit, Massachusetts General Hospital, Boston MA 02114, USA

14 Stanley Center for Psychiatric Research, Broad Institute of MIT and Harvard, Cambridge MA 02142, USA

15 Department of Psychiatry and Behavioral Sciences, SUNY Downstate Health Sciences University, Brooklyn, NY, US

${ }^{16}$ VA NY Harbor Healthcare System, Brooklyn, NY, US

17 Department of Psychiatry and Psychotherapy, Philipps-University Marburg, Germany

${ }^{18}$ Center for Mind, Brain and Behavior (CMBB), Marburg, Germany

${ }^{19}$ University of Munster, Department of Psychiatry

${ }^{20}$ Max Planck Institute of Psychiatry, Munich, Germany

21 Department of Genetic Epidemiology in Psychiatry, Central Institute of Mental Health, Medical Faculty Mannheim, Heidelberg University, Mannheim, Germany

${ }_{22}$ Centro de Investigación Biomedica en Red de Salud Mental (CIBERSAM), Barcelona, Spain.

${ }^{23}$ Division of Psychiatry, University of Edinburgh

24 Department of Clinical Sciences, Medical Faculty, Umeå University SE-901 87 Umeå 
medRxiv preprint doi: https://doi.org/10.1101/2021.04.16.21251163; this version posted April 16, 2021. The copyright holder for this preprint (which was not certified by peer review) is the author/funder, who has granted medRxiv a license to display the preprint in perpetuity. It is made available under a CC-BY-NC-ND 4.0 International license .

${ }^{25}$ Department of Clinical Neuroscience, Centre for Psychiatry Research, Karolinska Institutet, Stockholm, SE

${ }^{26}$ Department of Psychiatric Research, Diakonhjemmet Hospital, Oslo, NO

27 NORMENT Centre, Division of Mental Health and Addiction, Institute of Clinical Medicine and Diakonhjemmet Hospital, University of Oslo, Oslo, NO

${ }^{28}$ Division of Mental Health and Addiction, Oslo University Hospital, Oslo, Norway

${ }^{29}$ NORMENT Centre, Inst of Clinical Medicine, University of Oslo, Oslo, Norway

30 Department of Psychiatry and Psychotherapy, University Medical Center Göttingen, Göttingen, Germany

${ }^{31}$ Division of Mental Health and Addiction, Oslo University Hosptial, Oslo, Norway

32 Unit of Clinical Pharmacology, University Hospital Agency of Cagliari, Cagliari, Italy

${ }^{33}$ Geneva University Hospitals, Department of Psychiatry

34 University of Geneva, Faculty of medicine

35 Department of Psychiatry, Psychosomatic Medicine and Psychotherapy, University Hospital Frankfurt, Frankfurt am Main, Germany

${ }^{36}$ Universite de Paris, Paris, France

37 INSERM UMRS 1144, Paris, France

${ }^{38}$ APHP, DMU Neurosciences, GHU Lariboisière Fernand Widal, Departement de Psychiatrie, Paris, France

39 Hospital Clinic, University of Barcelona, IDIBAPS, CIBERSAM, Barcelona, Catalonia, Spain

40 Department of Psychiatry and Psychotherapeutic Medicine, Medical University Graz, Graz, Austria

${ }^{41}$ Psychiatry, University of Pennsylvania, Philadelphia, PA, US

42 Psychiatry, UMC Utrecht Brain Center, Utrecht, NL

43 Department of Psychiatry, Stony Brook University, Stony Brook, NY, USA

${ }^{44}$ Psychiatry, University of California San Francisco, San Francisco, CA, US

${ }^{45}$ Department of Psychiatry, McGill University, Montreal, Canada

${ }^{46}$ Department of Biomedicine, University of Basel, Basel, Switzerland

47 Institute of Human Genetics, University of Bonn, School of Medicine \& University Hospital Bonn, Bonn, Germany

48 Institute of Medical Genetics and Pathology, University Hospital Basel, Basel, Switzerland

49 Institute of Neuroscience and Medicine (INM-1), Research Centre Julich, Julich, Germany

${ }^{50}$ Discipline of Psychiatry, University of Adelaide, Australia

${ }^{51}$ Bazil Hetzel Institute, Woodville, South Australia, Australia

52 Department of Psychiatry \& Trinity Translational Medicine Institute, Trinity College Dublin, Ireland

${ }^{53}$ University of lowa Hospitals and Clinics, lowa City, IA, US

${ }^{54}$ Medical Research Council Centre for Neuropsychiatric Genetics and Genomics, Division of Psychological Medicine and Clinical Neurosciences

${ }^{55}$ Translational Genomics, USC, Los Angeles, CA, US

${ }^{56}$ Department of Psychiatry and Psychology, Mayo Clinic, Rochester, MN, US

57 Department of Psychiatric Genetics, Poznan University of Medical Sciences, Poznan, Poland

58 Department of Child and Adolescent Psychiatry, Psychosomatics and Psychotherapy, University Hospital Essen, University of Duisburg-Essen, Duisburg, Germany 
medRxiv preprint doi: https://doi.org/10.1101/2021.04.16.21251163; this version posted April 16, 2021. The copyright holder for this preprint (which was not certified by peer review) is the author/funder, who has granted medRxiv a license to display the preprint in perpetuity. It is made available under a CC-BY-NC-ND 4.0 International license .

806

807

808

809

810

811

812

813

814

815

816

817

818

819

820

821

822

823

824

825

826

827

828

829

830

831

832

833

834

835

836

837

838

839

840

841

842

843

844

845

846

847

848

849

850

851

852

853

854

855
59 Department of Psychiatry and Behavioral Sciences, Johns Hopkins University

${ }^{60}$ Department of Medical Genetics, Oslo University Hospital Ullevål, Oslo, NO

${ }^{61}$ NORMENT, Department of Clinical Science, University of Bergen, Bergen, NO

62 Department of Biochemistry and Molecular Biology, Indiana University School of

Medicine, Indianapolis, IN, USA

63 NORMENT, Division of Mental Health and Addiction, Oslo University Hospital,

Oslo, Norway

${ }^{64}$ Centre for Human Genetics, University of Marburg, Marburg, Germany

${ }^{65}$ Neuroscience Research Australia

${ }^{66}$ School of Medical Sciences, University of New South Wales

67 Department of Psychiatry and Psychotherapy, University Medical Center Göttingen, Germany

${ }^{68}$ Nova Scotia Health Authority, Halifax, Canada

69 Department of Psychiatry and Behavioral Neuroscience, University of Chicago, Chicago, IL, US

${ }^{70}$ Department of Human Genetics, University of Chicago, Chicago, IL, US

${ }^{71}$ Psychological Medicine, University of Worcester, UK

${ }^{72}$ Mood Disorders Centre of Ottawa, Ottawa, ON, Canada

${ }^{73}$ Dept of Psychiatry, University of Toronto, Toronto, ON, M5T 1R8, Canada

${ }^{74}$ Mental Health Department, University Regional Hospital, Biomedicine Institute (IBIMA), Málaga, Spain

${ }^{75}$ Universite Paris Est Creteil, Creteil, France

76 INSERM U 955, Neuropsychiatrie Translationnelle, Creteil, France

77 Department of Psychiatry and Neurochemistry, Institute of Neuroscience and Physiology, the Sahlgrenska Academy at the University of Gothenburg, Gothenburg, Sweden

${ }^{78}$ Department of Psychiatry, Icahn School of Medicine at Mount Sinai, New York, NY, US

${ }^{79}$ Department of Psychiatry, University of California San Diego, La Jolla, CA USA

80 The Campbell Family Mental Health Research Institute, Centre for Addiction and Mental Health, Toronto, ON, M5T 1R8, Canada

81 Institute of Medical Science, University of Toronto, Toronto, ON, M5S 1A8, Canada

82 Department of Psychiatry, Psychotherapy and Psychosomatics, University Hospital Wurzburg, Wurzburg, Germany

${ }^{83}$ Cell Biology, SUNY Downstate Medical Center College of Medicine, Brooklyn, NY, US

84 Institute for Genomic Health, SUNY Downstate Medical Center College of Medicine, Brooklyn, NY, US

85 Department of Medical Epidemiology and Biostatistics, Karolinska Institutet, Stockholm, Sweden

${ }^{86}$ Department of Psychiatry and Behavioral Sciences, Howard University Hospital, Washington, DC, US

${ }^{87}$ Neuroscience, Janssen Research \& Development, LLC, Titusville, NJ 08560, USA

88 Departmeent of Psychiatry, University of Campania "Luigi Vanvitelli", Naples, Italy

89 Department of Genetics \& Genomics, Icahn School of Medicine at Mount Sinai,

90 Unit of Psychiatry, Department of Public Health, Clinical \& Molecular Medicine, University of Cagliari, Cagliari, Italy

${ }^{91}$ Department of Pharmacology, Dalhousie University, Halifax, Nova Scotia, Canada

${ }^{92}$ Research Institute, Lindner Center of HOPE, Mason, OH, US 
medRxiv preprint doi: https://doi.org/10.1101/2021.04.16.21251163; this version posted April 16, 2021. The copyright holder for this preprint (which was not certified by peer review) is the author/funder, who has granted medRxiv a license to display the preprint in perpetuity. It is made available under a CC-BY-NC-ND 4.0 International license .

856

857

858

859

860

861

862

863

864

865

866

867

868

869

870

871

872

873

874

875

876

877

878

879

880

881

882

883

884

885

886

887

888

889

890

891

892

893

894

895

896

897

898

899

900

901

902

903

904

905
${ }^{93}$ Department of Psychiatry, University of Michigan, Ann Arbor, MI, US

${ }^{94}$ Psychiatric Clinic, Alexander University Hospital, Sofia, Bulgaria

${ }^{95}$ School of Psychiatry, University of New South Wales

96 Department of Medicine, Surgery and Dentistry "Scuola Medica Salernitana",

University of Salerno, Baronissi, Salerno, Italy

${ }^{97}$ National Institute of Mental Health, Klecany, Czech Republic

98 Psychiatry, Indiana University School of Medicine, Indianapolis, IN, US

99 Department of Psychiatry, Dalhousie University, Halifax, Canada

100 Dalhousie University

${ }^{101}$ Centre for Addiction and Mental Health, Toronto, Canada

102 University of Toronto

103 Department of Biomedical Science, Section of Neuroscience \& Clinical Pharmacology, University of Cagliari, Cagliari, Italy

${ }^{104}$ Department of Psychiatry and Behavioral Sciences, Emory University, Atlanta, GA

${ }^{105}$ Montreal Neurological Institute, Montreal, Canada

${ }^{106}$ Department of Neurology, McGill University, Montreal, Canada

107 Department of Psychiatry, Rush Medical College

108 Northern Adelaide Mental Health Service, SA Health, Salisbury, South Australia, Australia

109 Psychiatry and the Behavioral Sciences, University of Southern California, Los Angeles, CA, US

110 Department of Psychiatry, University of Perugia, Perugia, Italy

${ }^{111}$ Douglas Institute, McGill University, Montreal, Canada

112 Dalla Lana School of Public Health, Biostatistics Division, University of Toronto, Toronto, ON, M5G 2M9, Canada

${ }^{113}$ Laboratory Medicine and Pathobiology, University of Toronto, Toronto, ON, M5S 1A8, Canada

${ }^{114}$ Harvard T.H. Chan School of Public Health, 677 Huntington Ave, Boston, MA 02115, United States

115 Psychiatric and Neurodevelopmental Genetics Unit, Department of Psychiatry and Center for Genomic Medicine, Massachusetts General Hospital USA

116 Stanley Center for Psychiatric Research, Broad Institute of MIT and Harvard, USA

${ }_{117}$ Department of Health Sciences Research, Mayo Clinic, Rochester, MN, US

118 Human Genetics Branch, Intramural Research Program, National Institute of Mental Health, Bethesda, MD, US

119 Institute of Psychiatry, Psychology and Neuroscience, Kings College London, United Kingdom

${ }_{120}$ Human Genetics, University of California Los Angeles, Los Angeles, CA, US

${ }^{121}$ Department of Neurology, Klinikum rechts der Isar, School of Medicine, Technical

University of Munich, Munich, Germany

122 Department of Psychiatry and Behavioral Sciences, Johns Hopkins University School of Medicine, Baltimore, MD, USA

${ }^{123}$ Department of Psychiatry and Behavioral Sciences, SUNY Upstate Medical University, Syracuse, NY, USA

${ }^{124}$ Psychiatry, Erasmus University Medical Center, Rotterdam, The Netherlands 
medRxiv preprint doi: https://doi.org/10.1101/2021.04.16.21251163; this version posted April 16, 2021. The copyright holder for this preprint (which was not certified by peer review) is the author/funder, who has granted medRxiv a license to display the preprint in perpetuity.

\section{It is made available under a CC-BY-NC-ND 4.0 International license .}

906

907

908 
910 Table 1. Sample characteristics of datasets used in genetic analyses

\begin{tabular}{|c|c|c|c|c|c|c|c|c|}
\hline $\begin{array}{l}\text { GWAS } \\
\text { stage }\end{array}$ & Dataset & $\mathbf{N}$ & Continent & $\begin{array}{l}\text { Diagnosis, } \\
\% \text { BD-I }\end{array}$ & $\begin{array}{l}\text { Sex, } \\
\% \text { male }\end{array}$ & $\begin{array}{l}\text { AAO, median } \\
\text { (MAD+, range) }\end{array}$ & Definition of AAO & PAO* $^{*} \mathbf{N}(\%)$ \\
\hline \multirow[t]{17}{*}{ Discovery } & wtccc & 1452 & Europe & $89.53 \%$ & $36.85 \%$ & $24(8.9,9-63)$ & Impairment / help-seeking & \\
\hline & $\operatorname{tgco2}$ & 865 & $\begin{array}{l}\text { North } \\
\text { America }\end{array}$ & $100 \%$ & $33.64 \%$ & $17(5.93,8-46)$ & Diagnostic interview & $\begin{array}{l}\text { PAO-M: } 316 \text { (38.92\%); } \\
\text { PAO-D: } 496 \text { (61.08\%) }\end{array}$ \\
\hline & gain & 797 & $\begin{array}{l}\text { North } \\
\text { America }\end{array}$ & $100 \%$ & $48.06 \%$ & $18(5.93,8-45)$ & Diagnostic interview & $\begin{array}{l}\text { PAO-M: } 135 \text { (18.57\%); } \\
\text { PAO-D: } 440 \text { (60.52\%) }\end{array}$ \\
\hline & stp1 & 718 & $\begin{array}{l}\text { North } \\
\text { America }\end{array}$ & $100 \%$ & $44.01 \%$ & $16(5.93,8-41)$ & Diagnostic interview & $\begin{array}{l}\text { PAO-M: } 137 \text { (19.08\%); } \\
\text { PAO-D: } 420 \text { (58.5\%) }\end{array}$ \\
\hline & gsk1 & 715 & $\begin{array}{l}\text { North } \\
\text { America }\end{array}$ & $89.51 \%$ & $36.36 \%$ & $19(7.51,8-52)$ & Diagnostic interview & $\begin{array}{l}\text { PAO-M: } 102(14.61 \%) \\
\text { PAO-D: } 395 \text { (56.59\%) }\end{array}$ \\
\hline & usc2 & 681 & $\begin{array}{l}\text { North } \\
\text { America }\end{array}$ & $96.18 \%$ & $47.58 \%$ & $18(7.41,8-48)$ & Impairment / help-seeking & \\
\hline & bonn & 638 & Europe & $99.84 \%$ & $47.34 \%$ & $25(8.9,9-64)$ & Impairment / help-seeking & \\
\hline & ucl2 & 604 & Europe & $100 \%$ & $44.37 \%$ & $30(11.86,9-60)$ & Pharmacotherapy & $\begin{array}{l}\text { PAO-M: } 47 \text { (9.96\%); } \\
\text { PAO-D: } 209 \text { (44.28\%) }\end{array}$ \\
\hline & bmg3 & 455 & Europe & $57.14 \%$ & $40.66 \%$ & $24(10.38,10-62)$ & Impairment / help-seeking & $\begin{array}{l}\text { PAO-M: } 43(16.35 \%) \\
\text { PAO-D: } 159(60.46 \%)\end{array}$ \\
\hline & m\&m's & 449 & Europe & $74.83 \%$ & $52.12 \%$ & $23(10.38,8-65)$ & Mixed & $\begin{array}{l}\text { PAO-M: } 73(17.14 \%) ; \\
\text { PAO-D: } 238 \text { (55.87\%) }\end{array}$ \\
\hline & uclo & 439 & Europe & $100 \%$ & $39.86 \%$ & $22(7.41,8-51)$ & Impairment / help-seeking & $\begin{array}{l}\text { PAO-M: } 54 \text { (14.25\%); } \\
\text { PAO-D: } 197 \text { (51.98\%) }\end{array}$ \\
\hline & fran & 411 & Europe & $77.62 \%$ & $41.36 \%$ & $22(7.41,10-58)$ & Diagnostic interview & \\
\hline & euoR & 410 & Europe & $75.85 \%$ & $44.15 \%$ & $22(9.64,11-59)$ & Mixed & \\
\hline & hal2 & 355 & $\begin{array}{l}\text { North } \\
\text { America }\end{array}$ & $71.55 \%$ & $42.54 \%$ & $23(8.9,8-56)$ & Diagnostic interview & $\begin{array}{l}\text { PAO-M: } 102 \text { (29.65\%); } \\
\text { PAO-D: } 213 \text { (61.92\%) }\end{array}$ \\
\hline & ume4 & 354 & Europe & $69.21 \%$ & $37.85 \%$ & $20(8.9,8-63)$ & Diagnostic interview & $\begin{array}{l}\text { PAO-M: } 54 \text { (14.25\%); } \\
\text { PAO-D: } 197 \text { (51.98\%) }\end{array}$ \\
\hline & swa2 & 344 & Europe & $81.10 \%$ & $41.86 \%$ & $23(10.38,10-70)$ & Impairment / help-seeking & \\
\hline & bmpo & 319 & Europe & $78.06 \%$ & $39.18 \%$ & $28(11.86,10-63)$ & Impairment / help-seeking & $\begin{array}{l}\text { PAO-M: } 41(16.33 \%) ; \\
\text { PAO-D: } 150 \text { (59.76\%) }\end{array}$ \\
\hline
\end{tabular}




\begin{tabular}{|c|c|c|c|c|c|c|c|c|}
\hline & top7 & 301 & Europe & $62.79 \%$ & $41.53 \%$ & $19(7.41,8-49)$ & Diagnostic interview & \\
\hline & may1 & 257 & $\begin{array}{l}\text { North } \\
\text { America }\end{array}$ & $100 \%$ & $45.14 \%$ & $20(8.9,8-62)$ & Diagnostic interview & $\begin{array}{l}\text { PAO-M: } 34 \text { (13.23\%); } \\
\text { PAO-D: } 142(55.25 \%)\end{array}$ \\
\hline & bmsp & 248 & Europe & $94.76 \%$ & $45.56 \%$ & $22(7.41,9-57)$ & Impairment / help-seeking & $\begin{array}{l}\text { PAO-M: } 24 \text { (10.04\%); } \\
\text { PAO-D: } 93 \text { (38.91\%) }\end{array}$ \\
\hline & bmau & 245 & Australia & $79.18 \%$ & $40.82 \%$ & $19(7.41,8-55)$ & Diagnostic interview & $\begin{array}{l}\text { PAO-M: } 46 \text { (20.18\%); } \\
\text { PAO-D: } 125 \text { (54.82\%) }\end{array}$ \\
\hline & edi1 & 244 & Europe & $99.18 \%$ & $42.62 \%$ & $20(5.93,13-50)$ & Diagnostic interview & \\
\hline & rom3 & 226 & Europe & $100 \%$ & $41.15 \%$ & $25(10.38,12-59)$ & Diagnostic interview & $\begin{array}{l}\text { PAO-M: } 91 \text { (40.27\%); } \\
\text { PAO-D: } 134(59.29 \%)\end{array}$ \\
\hline & butr & 204 & Europe & $100 \%$ & $40.2 \%$ & $22(5.19,13-44)$ & Impairment / help-seeking & \\
\hline & euol & 191 & Europe & $74.87 \%$ & $31.41 \%$ & $24(8.9,13-67)$ & Diagnostic interview & $\begin{array}{l}\text { PAO-M: } 48(27.43 \%) \\
\text { PAO-D: } 98(56 \%)\end{array}$ \\
\hline & ageu & 178 & Europe & $90.45 \%$ & $39.33 \%$ & $21(7.41,8-51)$ & Impairment / help-seeking & \\
\hline & mich & 169 & $\begin{array}{l}\text { North } \\
\text { America }\end{array}$ & $100 \%$ & $31.36 \%$ & $18(5.93,8-45)$ & Diagnostic interview & $\begin{array}{l}\text { PAO-M: } 42 \text { (24.85\%); } \\
\text { PAO-D: } 84 \text { (49.7\%) }\end{array}$ \\
\hline & naom & 159 & $\begin{array}{l}\text { North } \\
\text { America }\end{array}$ & $84.91 \%$ & $44.65 \%$ & $18(7.41,8-66)$ & Mixed & $\begin{array}{l}\text { PAO-M: } 30 \text { (28.85\%); } \\
\text { PAO-D: } 51(49.04 \%)\end{array}$ \\
\hline & bmg2 & 152 & Europe & $59.87 \%$ & $35.53 \%$ & $27(10.38,13-63)$ & Impairment / help-seeking & \\
\hline & top8 & 111 & Europe & $55.86 \%$ & $37.84 \%$ & $18(7.41,8-49)$ & Diagnostic interview & \\
\hline & h66x & 92 & Europe & $82.61 \%$ & $36.96 \%$ & $30(10.38,9-55)$ & Mixed & \\
\hline & auom & 85 & Australia & $88.24 \%$ & $45.88 \%$ & $25(10.38,8-64)$ & Diagnostic interview & \\
\hline & euo2 & 58 & Europe & $65.52 \%$ & $56.9 \%$ & $26(8.9,18-57)$ & Diagnostic interview & \\
\hline & dub1 & 51 & Europe & $100 \%$ & $54.9 \%$ & $21(5.93,12-45)$ & Diagnostic interview & \\
\hline & Summary & 12977 & & $88.27 \%$ & $41.57 \%$ & $21(8.9,8-70)$ & & $\begin{array}{l}\text { PAO-M: } 1435 \text { (21.19\%); } \\
\text { PAO-D: } 3885 \text { (57.36\%) }\end{array}$ \\
\hline Replication & ukwa1 & 1156 & Europe & $75.17 \%$ & $38.15 \%$ & $23(8.9,8-74)$ & Impairment / help-seeking & \\
\hline & dutch & 468 & Europe & $100 \%$ & $42.31 \%$ & $28(10.38,11-63)$ & Pharmacotherapy & \\
\hline & jst5 & 186 & $\begin{array}{l}\text { North } \\
\text { America }\end{array}$ & $100 \%$ & $53.23 \%$ & $16(7.41,8-51)$ & Unknown & \\
\hline & colo & 176 & $\begin{array}{l}\text { South } \\
\text { America }\end{array}$ & $90.34 \%$ & $31.82 \%$ & $20(11.86,8-52)$ & Diagnostic interview & \\
\hline & bmrom & 126 & Europe & $100 \%$ & $42.86 \%$ & $24(8.9,12-56)$ & Diagnostic criteria & \\
\hline
\end{tabular}




\begin{tabular}{|l|l|l|l|l|l|l|l|l|}
\hline & bdtrs & 125 & Europe & $64 \%$ & $45.6 \%$ & $28(13.34,8-65)$ & Impairment / help-seeking & \\
\cline { 2 - 9 } & Summary & $\mathbf{2 2 3 7}$ & & $\mathbf{8 4 . 4 0 \%}$ & $\mathbf{4 0 . 4 6 \%}$ & $\mathbf{2 4}(\mathbf{1 0 . 3 8 , 8 - 7 4 )}$ & & \\
\hline All data & & $\mathbf{1 5 2 1 4}$ & & $\mathbf{8 6 . 2 6 \%}$ & $\mathbf{4 1 . 4 1 \%}$ & $\mathbf{2 2 ( \mathbf { 8 . 9 } , \mathbf { 8 - 7 4 ) }}$ & & \\
\hline
\end{tabular}

Abbreviations: GWAS, genome-wide association study; BD-I, bipolar disorder type I., AAO, age at onset; MAD, mean absolute deviation, PAO, polarity at onset;

$913+$ We calculated the mean absolute deviation using 1.4826 as constant.

914 *We defined three categories of polarity at onset: PAO-M, mania/hypomania before depression; PAO-D, depression before

915 mania/hypomania; and PAO-X, mixed. PAO was not available for all patients. The table presents the PAO-M and PAO-D subgroups

916 and their percentage within the individual cohorts. 
917 Table 2. The association of age and polarity at onset with disease characteristics in two European BD cohorts

\begin{tabular}{|c|c|c|c|c|c|c|c|c|c|c|c|}
\hline \multirow{2}{*}{$\begin{array}{l}\text { Disease } \\
\text { characteristic }\end{array}$} & \multicolumn{5}{|c|}{ AAO } & \multirow[b]{2}{*}{$\mathbf{N}$} & \multicolumn{4}{|c|}{ PAO } & \\
\hline & $\mathbf{N}$ & Odds ratio & $95 \% \mathrm{Cl}$ & $\begin{array}{l}\text { Unadjusted } \\
P \text { value }\end{array}$ & Adjusted $P$ value ${ }^{\star}$ & & Odds ratio & $95 \% \mathrm{Cl}$ & Unadjusted $P$ value & Adjusted $P$ value & \\
\hline Delusions & 1612 & 0.71 & $0.64-0.79$ & $1.61 \times 10^{-9}$ & $1.45 \times 10^{-8}$ & 1298 & 0.62 & $0.49-0.79$ & $1.04 \times 10^{-4}$ & $6.24 \times 10^{-4}$ & \\
\hline Hallucinations & 1594 & 0.83 & $0.74-0.92$ & $3.5 \times 10^{-4}$ & $1.40 \times 10^{-3}$ & 1290 & 0.93 & $0.74-1.17$ & $5.22 \times 10^{-1}$ & $1.00 \times 10^{0}$ & 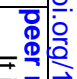 \\
\hline $\begin{array}{l}\text { Current } \\
\text { smoking }\end{array}$ & 1594 & 0.98 & $0.89-1.09$ & $7.50 \times 10^{-1}$ & $7.50 \times 10^{-1}$ & 1282 & 1.12 & $0.89-1.41$ & $3.39 \times 10^{-1}$ & $1.00 \times 10^{0}$ & \\
\hline $\begin{array}{l}\text { Suicide } \\
\text { attempt }\end{array}$ & 1537 & 0.78 & $0.69-0.88$ & $2.73 \times 10^{-5}$ & $1.64 \times 10^{-4}$ & 1262 & 1.58 & $1.24-2.02$ & $2.67 \times 10^{-4}$ & $1.34 \times 10^{-3}$ & \\
\hline $\begin{array}{l}\text { Educational } \\
\text { attainment }\end{array}$ & 1636 & 1.17 & $1.06-1.29$ & $2.77 \times 10^{-3}$ & $8.31 \times 10^{-3}$ & 1319 & 1.06 & $0.85-1.33$ & $5.93 \times 10^{-1}$ & $1.00 \times 10^{0}$ & \\
\hline $\begin{array}{l}\text { Living } \\
\text { together }\end{array}$ & 1357 & 1.28 & $1.15-1.44$ & $1.01 \times 10^{-5}$ & $8.08 \times 10^{-5}$ & - & - & - & - & - & \\
\hline & & Estimate $^{\star \star}$ & SE & $\begin{array}{l}\text { Unadjusted } \\
P \text { value }\end{array}$ & Adjusted $P$ value ${ }^{*}$ & & Estimate & SE & Unadjusted $P$ value & Adjusted $P$ value & \\
\hline $\begin{array}{l}\text { Number of } \\
\text { manic } \\
\text { episodes per } \\
\text { illness year }\end{array}$ & 1436 & 0.11 & 0.03 & $7.08 \times 10^{-5}$ & $3.54 \times 10^{-4}$ & 1156 & -0.42 & 0.06 & $4.68 \times 10^{-13}$ & $3.74 \times 10^{-12}$ & 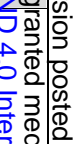 \\
\hline $\begin{array}{l}\text { Number of } \\
\text { depressive } \\
\text { episodes per } \\
\text { illness year }\end{array}$ & 1231 & 0.07 & 0.03 & $1.93 \times 10^{-2}$ & $3.86 \times 10^{-2}$ & 1051 & 0.12 & 0.06 & $4.63 \times 10^{-2}$ & $1.85 \times 10^{-1}$ & 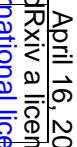 \\
\hline $\begin{array}{l}\text { Abbreviatior } \\
\text { N: total num } \\
\text { The number } \\
\text { corrected fo } \\
\text { * After Bonf } \\
\text { ** Unstanda }\end{array}$ & $\begin{array}{l}\text { s: AA } \\
\text { ber ot } \\
\text { of } m \\
\text { the y } \\
\text { rroni- } \\
\text { dizec }\end{array}$ & $\begin{array}{l}\text { age at on } \\
\text { articipants } \\
\text { c/depress } \\
\text { rs of illnes } \\
\text { Im correc } \\
\text { eta coeffic }\end{array}$ & $\begin{array}{l}\text { t; PAO, } \\
\text { om the } D \\
\text { episode } \\
\text { see the } \\
\text { n. Signifi } \\
\text { nt }\end{array}$ & $\begin{array}{l}\text { arity at ons } \\
h \text { and Gerr } \\
\text { vas divided } \\
\text { oplemental } \\
\text { t adjusted }\end{array}$ & $\begin{array}{l}\text { an cohorts } \\
\text { Material. } \\
\text { values are indic }\end{array}$ & +1. & econdar & nalyses & the number of ep & des not & 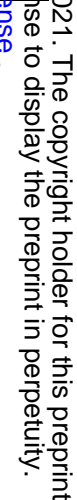 \\
\hline
\end{tabular}


medRxiv preprint doi: https://doi.org/10.1101/2021.04.16.21251163; this version posted April 16, 2021. The copyright holder for this preprint (which was not certified by peer review) is the author/funder, who has granted medRxiv a license to display the preprint in perpetuity.

It is made available under a CC-BY-NC-ND 4.0 International license .

926 Figure 1: Differences between phenotype definitions and continents across the 34

927 datasets used for genetic analyses

928 A: The various datasets used four different definitions for age at onset: diagnostic

929 interview, impairment/help-seeking, pharmacotherapy, and mixed.

930 B: The untransformed age at onset differed significantly, depending on the

931 phenotype definition used.

932 C: Estimation of the variance in different phenotype definitions explained by

933 genotyped single-nucleotide variants $\left(h^{2}{ }_{S N V}\right)$. For the cohort wtccc, we directly

934 estimated $h_{S N V}^{2}$ from genotype data in GCTA GREML; we estimated all other

935 heritabilities from GWAS summary statistics in LDSC. The plot shows $h^{2}{ }_{S N V}$

936 estimates and SEs.

937 Abbreviations: P, pharmacotherapy; I, impairment/help-seeking; M, mixed; D,

938 diagnostic interview; n.s., $P>0.05$; ${ }^{* * *} P<0.001$, SNV, single-nucleotide variant; cont,

939 continent; AAO, age at onset; BD-I, BD type I; PAO, polarity at onset; PAO-M,

940 mania/hypomania before depression; PAO-D, depression before mania/hypomania;

941 PAO-X, mixed.

942

943 Figure 2: Results from the genome-wide association study (GWAS) and polygenic

944 score (PGS) analyses of bipolar disorder (BD) age at onset (AAO)

945 A: Manhattan plot of the discovery-stage GWAS

946 B: Locus-specific Manhattan plot of the top-associated variant. Mbp, mega base

947 pairs; cM, centi Morgan

948 C-D: Results from analyses of PGS. For detailed results, see Supplementary Table

949 S8. Significance levels: n.s., $P>0.05$; Nominal: $P<0.05$; Bonferroni, below the

950 Bonferroni-corrected significance threshold corrected for 96 tests $\left(P<5.2 \times 10^{-4}\right)$. 
medRxiv preprint doi: https://doi.org/10.1101/2021.04.16.21251163; this version posted April 16, 2021. The copyright holder for this preprint

(which was not certified by peer review) is the author/funder, who has granted medRxiv a license to display the preprint in perpetuity.

It is made available under a CC-BY-NC-ND 4.0 International license.

951 Abbreviations: ADHD, attention deficit/hyperactivity disorder; ASD, autism spectrum

952 disorder; MD, major depression; SZ, schizophrenia; EA, educational attainment.

953 C: Associations of PGSs with the age at onset (AAO). For interpretability, the plot

954 shows the untransformed AAO. Significance levels are based on the analyses of the

955 AAO after rank-based inverse normal transformation (which was performed because

956 the distribution of AAO was highly skewed and differed greatly across the study

957 cohorts).

958 D: Associations of the top vs bottom AAO quartiles with the top vs bottom PGS

959 quartiles. A higher odds ratio (OR) indicates an association with higher AAO.

960

961

962

963

964

965

966

967

968

969

970

971

972

973

974

975

976 
medRxiv preprint doi: https://doi.org/10.1101/2021.04.16.21251163; this version posted April 16, 2021. The copyright holder for this preprint (which was not certified by peer review) is the author/funder, who has granted medRxiv a license to display the preprint in perpetuity.

979

980

981

982

983

984

985

986

987

988

989

990

991

992

993

994

995

996

997

998

999

1000

1001

1002

1003

1004

1005

1006

1007

1008

1009

1010

1011

1012

1013

1014

1015

1016

1017

1018

1019

1020

1021

1022

1023

1024

1025

\section{References}

1. Merikangas KR, Jin R, He J-P, Kessler RC, Lee S, Sampson NA, et al. Prevalence and Correlates of Bipolar Spectrum Disorder in the World Mental Health Survey Initiative. Arch Gen Psychiatry [Internet]. 2011 Mar 7 [cited 2018 Jul 18];68(3):241. Available from: http://archpsyc.jamanetwork.com/article.aspx?doi=10.1001/archgenpsychiatry. 2011.12

2. Whiteford HA, Degenhardt L, Rehm J, Baxter AJ, Ferrari AJ, Erskine HE, et al. Global burden of disease attributable to mental and substance use disorders: findings from the Global Burden of Disease Study 2010. Lancet [Internet]. 2013 Nov [cited 2018 Apr 11];382(9904):1575-86. Available from: http://linkinghub.elsevier.com/retrieve/pii/S0140673613616116

3. Cloutier M, Greene M, Guerin A, Touya M, Wu E. The economic burden of bipolar I disorder in the United States in 2015. J Affect Disord [Internet]. 2018 Jan 15 [cited 2018 Oct 23];226:45-51. Available from: http://www.ncbi.nlm.nih.gov/pubmed/28961441

4. Berk M, Dodd S, Callaly P, Berk L, Fitzgerald P, de Castella AR, et al. History of illness prior to a diagnosis of bipolar disorder or schizoaffective disorder. $\mathrm{J}$ Affect Disord [Internet]. 2007 Nov [cited 2020 Aug 29];103(1-3):181-6. Available from: https://pubmed.ncbi.nlm.nih.gov/17324469/

5. Dagani J, Signorini G, Nielssen O, Bani M, Pastore A, Girolamo G de, et al. Meta-analysis of the Interval between the Onset and Management of Bipolar Disorder. Can J Psychiatry [Internet]. 2017 Apr 26 [cited 2019 May 17];62(4):247-58. Available

from: http://www.ncbi.nlm.nih.gov/pubmed/27462036

6. Cleynen I, Boucher G, Jostins L, Schumm LP, Zeissig S, Ahmad T, et al. Inherited determinants of Crohn's disease and ulcerative colitis phenotypes: A genetic association study. Lancet [Internet]. 2016 [cited 2020 Apr 19];387(10014):156-67. Available from: https://pubmed-ncbi-nlm-nihgov.treadwell.idm.oclc.org/26490195/

7. Bergen SE, O'Dushlaine CT, Lee PH, Fanous AH, Ruderfer DM, Ripke S, et al. Genetic modifiers and subtypes in schizophrenia: Investigations of age at onset, severity, sex and family history. Schizophr Res [Internet]. 2014;154(13):48-53. Available from: http://dx.doi.org/10.1016/j.schres.2014.01.030

8. óNaj AC, Jun G, Reitz C, Kunkle BW, Perry W, Park YS, et al. Effects of multiple genetic loci on age at onset in late-onset Alzheimer disease: A genome-wide association study. JAMA Neurol. 2014 Nov 1;71(11):1394-404.

9. Rhebergen D, Lamers F, Spijker J, De Graaf R, Beekman ATF, Penninx BWJH. Course trajectories of unipolar depressive disorders identified by latent class growth analysis. Psychol Med. 2012;42(7):1383-96.

10. Howes OD, Lim S, Theologos G, Yung AR, Goodwin GM, McGuire P. A comprehensive review and model of putative prodromal features of bipolar affective disorder [Internet]. Vol. 41, Psychological Medicine. Psychol Med; 2011 [cited 2020 Jul 26]. p. 1567-77. Available from: https://pubmed.ncbi.nlm.nih.gov/20836910/

11. Wijnands JMA, Kingwell E, Zhu F, Zhao Y, Högg T, Stadnyk K, et al. Healthcare use before a first demyelinating event suggestive of a multiple sclerosis 
medRxiv preprint doi: https://doi.org/10.1101/2021.04.16.21251163; this version posted April 16, 2021. The copyright holder for this preprint (which was not certified by peer review) is the author/funder, who has granted medRxiv a license to display the preprint in perpetuity. It is made available under a CC-BY-NC-ND 4.0 International license .

prodrome: a matched cohort study. Lancet Neurol [Internet]. 2017 Jun 1 [cited 2020 Jul 26];16(6):445-51. Available from: https://pubmed.ncbi.nlm.nih.gov/28434855/

12. Smoller JW, Finn CT. Family, twin, and adoption studies of bipolar disorder. Am J Med Genet Part C Semin Med Genet [Internet]. 2003 Nov 15 [cited 2020 Jun 8];123C(1):48-58. Available from: http://doi.wiley.com/10.1002/ajmg.c.20013

13. Rice J, Reich T, Andreasen NC, Endicott J, Van Eerdewegh M, Fishman R, et al. The Familial Transmission of Bipolar Illness. Arch Gen Psychiatry. 1987;44(5):441-7.

14. Hafeman DM, Merranko J, Goldstein TR, Axelson D, Goldstein BI, Monk K, et al. Assessment of a Person-Level Risk Calculator to Predict New-Onset Bipolar Spectrum Disorder in Youth at Familial Risk. JAMA Psychiatry [Internet]. 2017 Aug 1 [cited 2018 Oct 18];74(8):841. Available from: http://archpsyc.jamanetwork.com/article.aspx?doi=10.1001/jamapsychiatry.201 7.1763

15. Belmonte Mahon P, Pirooznia M, Goes FS, Seifuddin F, Steele J, Lee PH, et al. Genome-wide association analysis of age at onset and psychotic symptoms in bipolar disorder. Am J Med Genet B Neuropsychiatr Genet [Internet]. 2011 Apr [cited 2015 Sep 29];156B(3):370-8. Available from: http://www.pubmedcentral.nih.gov/articlerender.fcgi?artid=3178836\&tool=pmce ntrez\&rendertype $=$ abstract

16. Ruderfer DM, Ripke S, McQuillin A, Boocock J, Stahl EA, Pavlides JMW, et al. Genomic Dissection of Bipolar Disorder and Schizophrenia, Including 28 Subphenotypes. Cell [Internet]. 2018 Jun;173(7):1705-1715.e16. Available from: https://linkinghub.elsevier.com/retrieve/pii/S0092867418306585

17. Jamain S, Cichon S, Etain B, Muhleisen TW, Georgi A, Zidane N, et al. Common and rare variant analysis in early-onset bipolar disorder vulnerability. PLoS One [Internet]. 2014 Jan [cited 2016 Aug 1];9(8):e104326. Available from:

http://www.pubmedcentral.nih.gov/articlerender.fcgi?artid=4128749\&tool=pmce ntrez\&rendertype $=$ abstract

18. Stahl EA, Breen G, Forstner AJ, McQuillin A, Ripke S, Trubetskoy V, et al. Genome-wide association study identifies 30 loci associated with bipolar disorder. Nat Genet [Internet]. 2019 [cited 2020 Feb 23];51(5):793-803. Available from: http://www.ncbi.nlm.nih.gov/pubmed/31043756

19. Coleman JRI, Gaspar HA, Bryois J, Byrne EM, Forstner AJ, Holmans PA, et al. The Genetics of the Mood Disorder Spectrum: Genome-wide Association Analyses of More Than 185,000 Cases and 439,000 Controls. Biol Psychiatry [Internet]. 2020 [cited 2020 May 3]; Available from: https://pubmed.ncbi.nlm.nih.gov/31926635/

20. Kalman JL, Papiol S, Forstner AJ, Heilbronner U, Degenhardt F, Strohmaier J, et al. Investigating polygenic burden in age at disease onset in bipolar disorder: Findings from an international multicentric study. Bipolar Disord [Internet]. 2019 Jun 28;21(1):68-75. Available from: http://doi.wiley.com/10.1111/bdi.12659

21. Aas M, Bellivier F, Bettella F, Henry C, Gard S, Kahn JP, et al. Childhood maltreatment and polygenic risk in bipolar disorders. Bipolar Disord [Internet]. 2020 Mar 1 [cited 2020 Nov 16];22(2):174-81. Available from: https://pubmed.ncbi.nlm.nih.gov/31628696/

22. Kassem L, Lopez V, Hedeker D, Steele J, Zandi P, Bipolar Disorder Consortium NGI, et al. Familiality of Polarity at Illness Onset in Bipolar Affective 
medRxiv preprint doi: https://doi.org/10.1101/2021.04.16.21251163; this version posted April 16, 2021. The copyright holder for this preprint (which was not certified by peer review) is the author/funder, who has granted medRxiv a license to display the preprint in perpetuity. It is made available under a CC-BY-NC-ND 4.0 International license .

Disorder. Am J Psychiatry [Internet]. 2006 Oct [cited 2018 Nov 15];163(10):1754-9. Available from: http://www.ncbi.nlm.nih.gov/pubmed/17012686

23. Ruderfer DM, Ripke S, McQuillin A, Boocock J, Stahl EA, Pavlides JMW, et al. Genomic Dissection of Bipolar Disorder and Schizophrenia, Including 28 Subphenotypes. Cell. 2018;173(7):1705-1715.e16.

24. Schulze TG, Alda M, Adli M, Akula N, Ardau R, Bui ET, et al. The International Consortium on Lithium Genetics (ConLiGen): an initiative by the NIMH and IGSLI to study the genetic basis of response to lithium treatment. Neuropsychobiology [Internet]. 2010 [cited 2017 Jul 1];62(1):72-8. Available from: http://www.karger.com/doi/10.1159/000314708

25. van Bergen AH, Verkooijen S, Vreeker A, Abramovic L, Hillegers MH, Spijker AT, et al. The characteristics of psychotic features in bipolar disorder. Psychol Med [Internet]. 2019 Sep 10 [cited 2020 May 17];49(12):2036-48. Available from:

https://www.cambridge.org/core/product/identifier/S0033291718002854/type/jo urnal_article

26. Budde M, Anderson-Schmidt H, Gade K, Reich-Erkelenz D, Adorjan K, Kalman $\mathrm{JL}$, et al. A longitudinal approach to biological psychiatric research: The PsyCourse study. Am J Med Genet B Neuropsychiatr Genet [Internet]. 2019 [cited 2020 Feb 23];180(2):89-102. Available from: http://www.ncbi.nlm.nih.gov/pubmed/30070057

27. Kircher T, Wöhr M, Nenadic I, Schwarting R, Schratt G, Alferink J, et al. Neurobiology of the major psychoses: a translational perspective on brain structure and function-the FOR2107 consortium. Eur Arch Psychiatry Clin Neurosci [Internet]. 2019 [cited 2020 May 3];269(8):949-62. Available from: https://pubmed.ncbi.nlm.nih.gov/30267149/

28. Perlis $\mathrm{RH}$, Miyahara S, Marangell LB, Wisniewski SR, Ostacher M, DelBello $\mathrm{MP}$, et al. Long-term implications of early onset in bipolar disorder: data from the first 1000 participants in the systematic treatment enhancement program for bipolar disorder (STEP-BD). Biol Psychiatry [Internet]. 2004 May 1 [cited 2020 Feb 22];55(9):875-81. Available from: http://www.ncbi.nlm.nih.gov/pubmed/15110730

29. Lam M, Awasthi S, Watson HJ, Goldstein J, Panagiotaropoulou G, Trubetskoy V, et al. RICOPILI: Rapid Imputation for COnsortias PIpeLIne. Bioinformatics [Internet]. 2020 [cited 2020 May 3];36(3):930-3. Available from: https://pubmed.ncbi.nlm.nih.gov/31393554/

30. Howie BN, Donnelly P, Marchini J. A Flexible and Accurate Genotype Imputation Method for the Next Generation of Genome-Wide Association Studies. Schork NJ, editor. PLoS Genet [Internet]. 2009 Jun 19 [cited 2020 May 19];5(6):e1000529. Available from: https://dx.plos.org/10.1371/journal.pgen.1000529

31. Purcell S, Neale B, Todd-Brown K, Thomas L, Ferreira MAR, Bender D, et al. PLINK: a tool set for whole-genome association and population-based linkage analyses. Am J Hum Genet [Internet]. 2007 Sep [cited 2017 Aug 5];81(3):559_ 75. Available from: http://linkinghub.elsevier.com/retrieve/pii/S0002929707613524

32. METAL: fast and efficient meta-analysis of genomewide association scans [Internet]. [cited 2020 Jun 14]. Available from: https://www.ncbi.nlm.nih.gov/pmc/articles/PMC2922887/

33. Demontis D, Walters RK, Martin J, Mattheisen M, Als TD, Agerbo E, et al. 
medRxiv preprint doi: https://doi.org/10.1101/2021.04.16.21251163; this version posted April 16, 2021. The copyright holder for this preprint (which was not certified by peer review) is the author/funder, who has granted medRxiv a license to display the preprint in perpetuity. It is made available under a CC-BY-NC-ND 4.0 International license .

Discovery of the first genome-wide significant risk loci for attention deficit/hyperactivity disorder. Nat Genet. 2019;51(1):63-75.

34. Grove J, Ripke S, Als TD, Mattheisen M, Walters RK, Won H, et al. Identification of common genetic risk variants for autism spectrum disorder. Nat Genet [Internet]. 2019 [cited 2020 Feb 26];51(3):431-44. Available from: http://www.ncbi.nlm.nih.gov/pubmed/30804558

35. Lee JJ, Wedow R, Okbay A, Kong E, Maghzian O, Zacher M, et al. Gene discovery and polygenic prediction from a genome-wide association study of educational attainment in 1.1 million individuals. Nat Genet. 2018 Aug 1;50(8):1112-21.

36. Howard DM, Adams MJ, Clarke TK, Hafferty JD, Gibson J, Shirali M, et al. Genome-wide meta-analysis of depression identifies 102 independent variants and highlights the importance of the prefrontal brain regions. Nat Neurosci. 2019 Mar 1;22(3):343-52.

37. Pardiñas AF, Holmans P, Pocklington AJ, Escott-Price V, Ripke S, Carrera N, et al. Common schizophrenia alleles are enriched in mutation-intolerant genes and in regions under strong background selection. Nat Genet. 2018 Mar 1;50(3):381-9.

38. Ge T, Chen CY, Ni Y, Feng YCA, Smoller JW. Polygenic prediction via Bayesian regression and continuous shrinkage priors. Nat Commun [Internet]. 2019 [cited 2020 May 19];10(1). Available from: https://pubmed.ncbi.nlm.nih.gov/30992449/?from_single_result=tian+ge+prs+c s\&expanded_search_query=tian+ge+prs+cs

39. Yang J, Lee SH, Goddard ME, Visscher PM. GCTA: A tool for genome-wide complex trait analysis. Am J Hum Genet. 2011 Jan 7;88(1):76-82.

40. Yang J, Benyamin B, McEvoy BP, Gordon S, Henders AK, Nyholt DR, et al. Common SNPs explain a large proportion of the heritability for human height. Nat Genet. 2010 Jul;42(7):565-9.

41. Bulik-Sullivan B, Loh PR, Finucane HK, Ripke S, Yang J, Patterson N, et al. LD score regression distinguishes confounding from polygenicity in genome-wide association studies. Nat Genet. 2015 Feb 25;47(3):291-5.

42. Heimbuch RC, Matthysse S, Kidd KK. Estimating age-of-onset distribution for disorders with variable onset. Am J Hum Genet [Internet]. 1980 [cited 2020 Sep 10];32(4):564-74. Available from: /pmc/articles/PMC1686126/?report=abstract

43. Larsson S, Lorentzen S, Mork E, Barrett EA, Steen NE, Lagerberg TV, et al. Age at onset of bipolar disorder in a Norwegian catchment area sample. $J$ Affect Disord. 2010 Jul 1;124(1-2):174-7.

44. Post RM, Luckenbaugh DA, Leverich GS, Altshuler LL, Frye MA, Suppes T, et al. Incidence of childhood-onset bipolar illness in the USA and Europe. $\mathrm{Br} \mathrm{J}$ Psychiatry [Internet]. 2008 Feb [cited 2020 Sep 14];192(2):150-1. Available from: https://www.cambridge.org/core.

45. Cai N, Revez JA, Adams MJ, Andlauer TFM, Breen G, Byrne EM, et al. Minimal phenotyping yields genome-wide association signals of low specificity for major depression. Nat Genet. 2020 Apr 1;52(4):437-47.

46. Andlauer TFM, Buck D, Antony G, Bayas A, Bechmann L, Berthele A, et al. Novel multiple sclerosis susceptibility loci implicated in epigenetic regulation. Sci Adv [Internet]. 2016 Jun 17 [cited 2017 Aug 22];2(6):e1501678. Available from: http://advances.sciencemag.org/cgi/doi/10.1126/sciadv.1501678

47. Vreeker A, Boks MPM, Abramovic L, Verkooijen S, Van Bergen AH, Hillegers $\mathrm{MHJ}$, et al. High educational performance is a distinctive feature of bipolar disorder: A study on cognition in bipolar disorder, schizophrenia patients, 
medRxiv preprint doi: https://doi.org/10.1101/2021.04.16.21251163; this version posted April 16, 2021. The copyright holder for this preprint (which was not certified by peer review) is the author/funder, who has granted medRxiv a license to display the preprint in perpetuity. It is made available under a CC-BY-NC-ND 4.0 International license .

relatives and controls. Psychol Med [Internet]. 2016 Mar 1 [cited 2020 Nov 16];46(4):807-18. Available from: https://pubmed.ncbi.nlm.nih.gov/26621616/

48. MacCabe JH, Lambe MP, Cnattingius S, Sham PC, David AS, Reichenberg A, et al. Excellent school performance at age 16 and risk of adult bipolar disorder: National cohort study. Br J Psychiatry [Internet]. 2010 Feb [cited 2020 Nov 16];196(2):109-15. Available from: https://pubmed.ncbi.nlm.nih.gov/20118454/

49. Mullins N, Forstner AJ, O\&\#039;Connell KS, Coombes B, Coleman JRI, Qiao Z, et al. Genome-wide association study of over 40,000 bipolar disorder cases provides novel biological insights. medRxiv [Internet]. 2020 Jan 1;2020.09.17.20187054. Available from: http://medrxiv.org/content/early/2020/09/18/2020.09.17.20187054.abstract

50. Robinson MR, Wray NR, Visscher PM. Explaining additional genetic variation in complex traits. Trends Genet [Internet]. 2014 [cited 2020 May 16];30(4):124. Available from: https://www.ncbi.nlm.nih.gov/pmc/articles/PMC4639398/

51. Montlahuc C, Curis E, Jonas SF, Bellivier F, Chevret S. Age-at-onset subsets of bipolar I disorders: A critical insight into admixture analyses. Int $\mathrm{J}$ Methods Psychiatr Res [Internet]. 2016 Oct 21 [cited 2017 Jul 27]; Available from: http://www.ncbi.nlm.nih.gov/pubmed/27766706

52. Cooper JE. Psychiatric diagnosis in New York and London; a comparative study of mental hospital admissions [Internet]. Maudsley monographs, no. 20. 1972 [cited 2020 Jun 26]. xi, 152. Available from: https://psycnet.apa.org/record/1973-23416-000

53. Bellivier F, Etain B, Malafosse A, Henry C, Kahn JP, Elgrabli-Wajsbrot O, et al. Age at onset in bipolar I affective disorder in the USA and Europe. World $\mathrm{J}$ Biol Psychiatry [Internet]. 2014 [cited 2020 Jun 27];15(5):369-76. Available from: https://pubmed.ncbi.nlm.nih.gov/22188366/

54. Birmaher B, Axelson D, Goldstein B, Strober M, Gill MK, Hunt J, et al. Fouryear longitudinal course of children and adolescents with bipolar spectrum disorders: the Course and Outcome of Bipolar Youth (COBY) study. Am J Psychiatry [Internet]. 2009 Jul [cited 2018 Oct 21];166(7):795-804. Available from: http://www.ncbi.nlm.nih.gov/pubmed/19448190

55. Daban C, Colom F, Sanchez-Moreno J, García-Amador M, Vieta E. Clinical correlates of first-episode polarity in bipolar disorder. Compr Psychiatry [Internet]. 2006 Nov [cited 2020 Jul 26];47(6):433-7. Available from: https://pubmed.ncbi.nlm.nih.gov/17067865/

56. Etain B, Lajnef M, Bellivier F, Mathieu F, Raust A, Cochet B, et al. Clinical expression of bipolar disorder type I as a function of age and polarity at onset: Convergent findings in samples from France and the United States. J Clin Psychiatry [Internet]. 2012 [cited 2020 Jul 26];73(4). Available from: https://pubmed.ncbi.nlm.nih.gov/22579163/

57. Cremaschi L, Dell'Osso B, Vismara M, Dobrea C, Buoli M, Ketter TA, et al. Onset polarity in bipolar disorder: A strong association between first depressive episode and suicide attempts. J Affect Disord [Internet]. 2017 Feb 1 [cited 2020 Jul 26];209:182-7. Available from: https://pubmed.ncbi.nlm.nih.gov/27936451/

58. Smoller JW. The use of electronic health records for psychiatric phenotyping and genomics. Am J Med Genet Part B Neuropsychiatr Genet. 2018;177(7):601-12.

59. Zhang Y, Cai T, Yu S, Cho K, Hong C, Sun J, et al. High-throughput phenotyping with electronic medical record data using a common semisupervised approach (PheCAP). Nat Protoc [Internet]. 2019;14(12):3426-44. Available from: http://dx.doi.org/10.1038/s41596-019-0227-6 
medRxiv preprint doi: https://doi.org/10.1101/2021.04.16.21251163; this version posted April 16, 2021. The copyright holder for this preprint (which was not certified by peer review) is the author/funder, who has granted medRxiv a license to display the preprint in perpetuity. It is made available under a CC-BY-NC-ND 4.0 International license.

60. Sullivan PF, Agrawal A, Bulik CM, Andreassen OA, Børglum AD, Breen G, et al. Psychiatric genomics: An update and an Agenda. Am J Psychiatry. 2018;175(1):15-27.

1233 
Figure 1: Differences between phenotype definitions and continents across the 34 datasets used for genetic analyses

A: The various datasets used four different definitions for age at onset: diagnostic interview, impairment/help-seeking, pharmacotherapy, and mixed.

B: The untransformed age at onset differed significantly, depending on the phenotype definition used. Abbreviations: P, pharmacotherapy; I, impairment/help-seeking; $M$, mixed; D, diagnostic interview; n.s., $P>0.05 ;{ }^{* * *} P<0.001$.

C: Estimation of the variance in different phenotype definitions explained by genotyped single-nucleotide variants $\left(h^{2} S N V\right)$. For the cohort wtccc, we directly estimated $h^{2} S N V$ from genotype data in GCTA GREML; we estimated all other heritabilities from GWAS summary statistics in LDSC. The plot shows $h^{2}$ SNV estimates and SEs. Abbreviations: SNV, single-nucleotide variant; cont, continent; AAO, age at onset; BD-I, BD type I; PAO, polarity at onset; PAO-M, mania/hypomania before depression; PAO-D, depression before mania/hypomania; PAO-X, mixed.
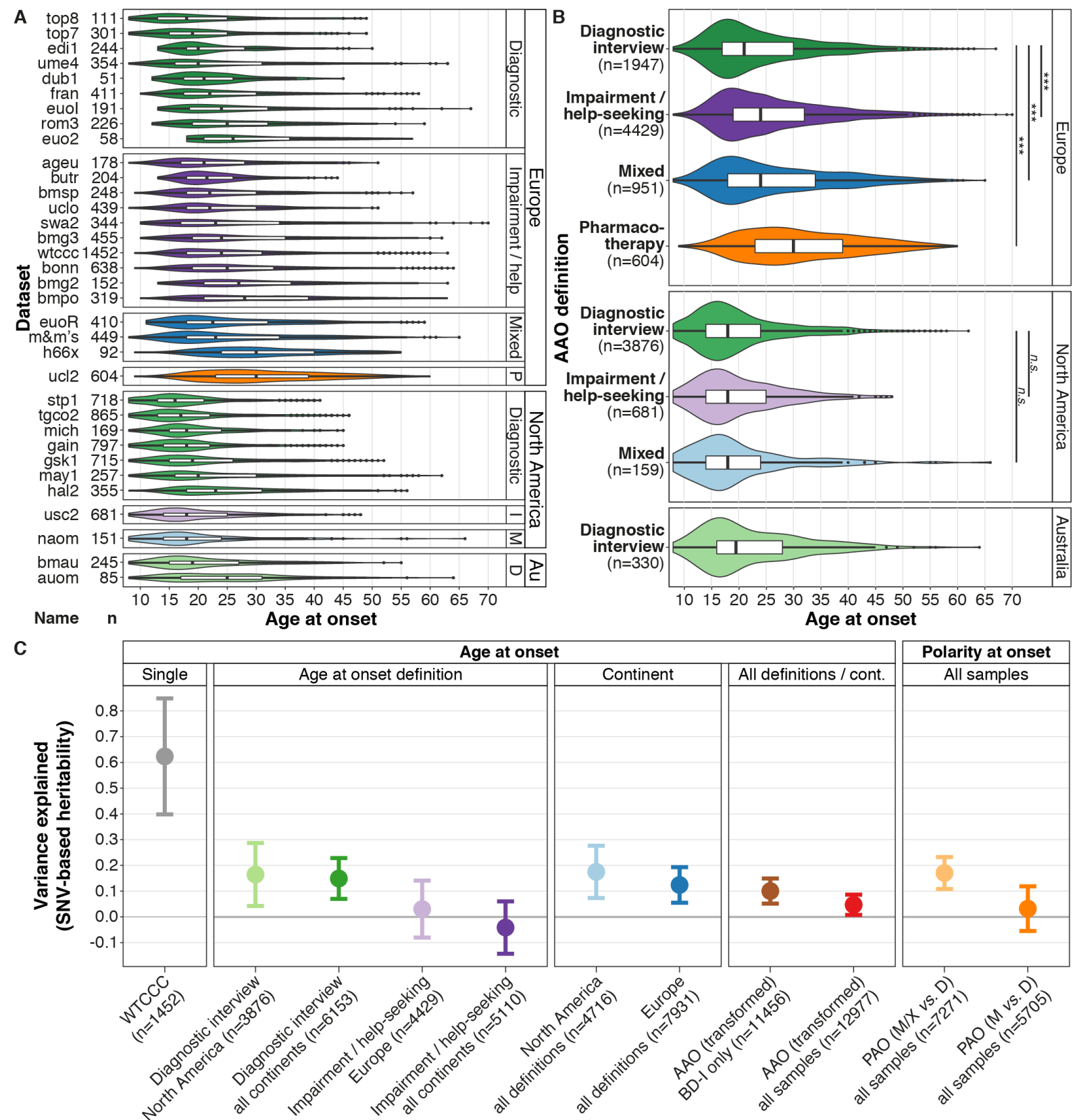
Figure 2: Results from the genome-wide association study (GWAS) and polygenic score (PGS) analyses of bipolar disorder (BD) age at onset (AAO)

A: Manhattan plot of the discovery-stage GWAS.

B: Locus-specific Manhattan plot of the top-associated variant. Mbp, mega base pairs; $\mathrm{CM}$, centi Morgan.

C-D: Results from analyses of PGS. For detailed results, see Supplementary Table S8. Significance levels: n.s., $P>0.05$; Nominal, $P<0.05$; Bonferroni, below the Bonferroni-corrected significance threshold corrected for 96 tests $\left(P<5.2 \times 10^{-4}\right)$. Abbreviations: ADHD, attention deficit/hyperactivity disorder; ASD, autism spectrum disorder; MD, major depression; SZ, schizophrenia; EA, educational attainment. C: For interpretability, the plot shows the untransformed AAO. Significance levels are based on the analyses of the AAO after rank-based inverse normal transformation (which was performed because the distribution of AAO was highly skewed and differed greatly across the study cohorts).

D: Associations of the top vs bottom AAO quartiles with the top vs bottom PGS quartiles. A higher odds ratio (OR) indicates an association with higher AAO.
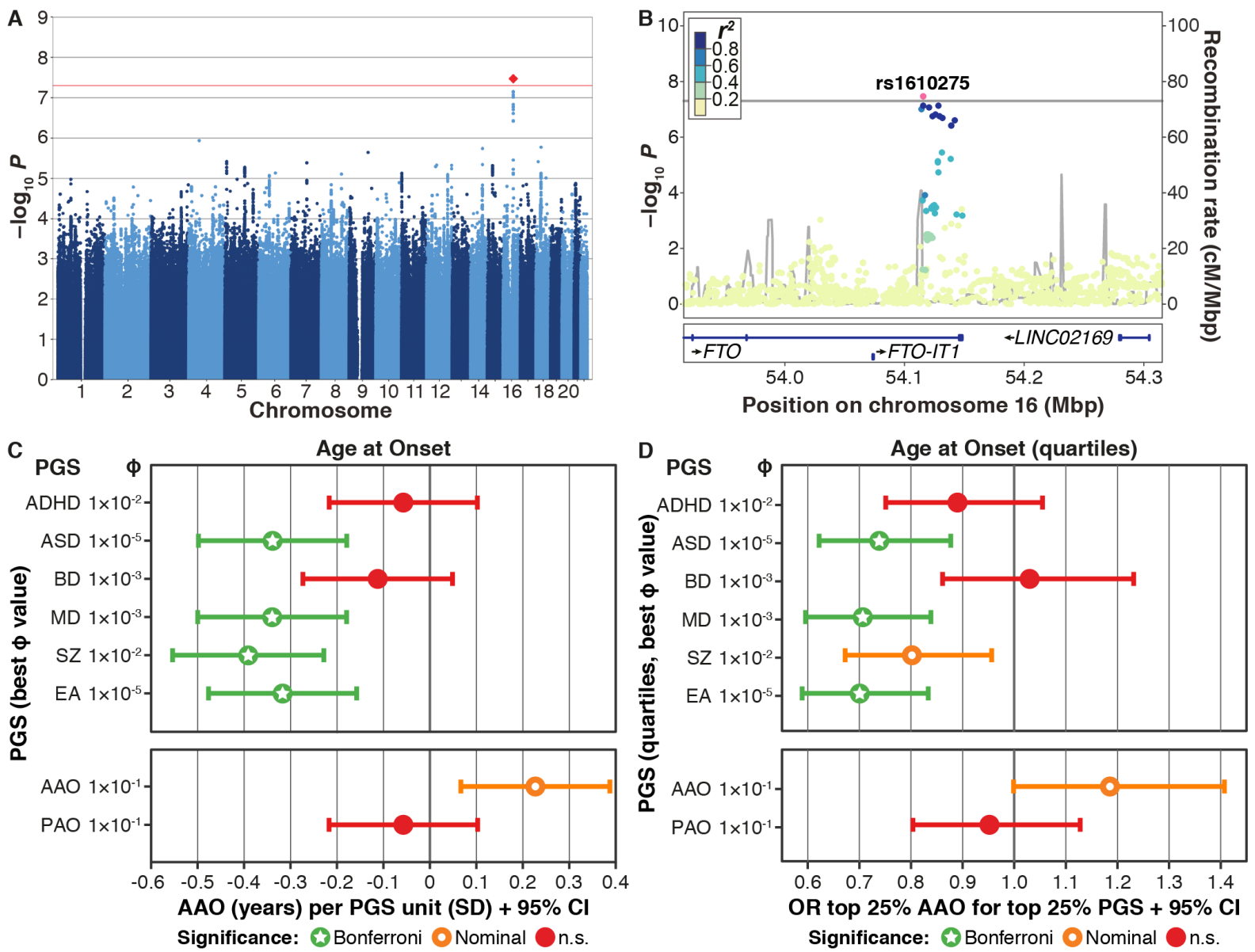